\title{
TALENTINGO PERSONALO ATRANKOS VEIKSNIAI: FARMACIJOS ORGANIZACIJŲ ATVEJIS
}

\author{
Doc. dr. Dileta Jatautaitė \\ Generolo Jono Žemaičio Lietuvos karo akademija
}

Indrẻ Janušauskienė

\begin{abstract}
Anotacija. Straipsnyje pristatomos ir analizuojamos talento ir kompetencijos sqvoku sampratos bei ju samplaika, orientavimo ir motyvavimo veiksniu svarba ilgalaikiam talentu išlaikymui. Straipsnio tikslas - išsiaiškinti ir išanalizuoti pagrindinius veiksnius, motyvuojančius talentingus darbuotojus likti ir efektyviai dirbti šiuolaikineje farmacijos organizacijoje.

Siekiant igyvendinti straipsnio tikslą ir iškeltus uždavinius, buvo atliktas tyrimas, pateikus 2018 metais parengta elektroninę anketa farmacijos organizaciju administracijos darbuotojams (vadovams ir specialistams). Remiantis surinktais duomenimis, buvo ivvertinta talentu svarba, išanalizuoti talentingu darbuotojų motyvavimo veiksniai, svarbūs personalo išlaikymui ir ju darbo efektyvumui.

Atliekant tyrima gauti rezultatai padejo išskirti ir išanalizuoti problemas, su kuriomis susiduria farmacijos organizacijos, norèdamos apsirūpinti talentingais darbuotojais, juos motyvuodamos efektyviai ir kokybiškai dirbti. Straipsnyje išanalizuoti tyrimo rezultatai padès rasti efektyviausius motyvavimo metodus, bütinus talentams išlaikyti ir situacijai organizacijoje pagerinti i talentu paieškos procesa ịtraukiant daugiau veiklų ar gerinant ju igyvendinima. Pritraukimas talentingo personalo - vienas svarbiausių organizacijos uždaviniu, čia itin svarbus pradinis etapas - supažindinimas su darbo specifika, organizacijos kultūra, kolektyvu ir kt. Lietuvos farmacijos organizaciju personalo tyrimo analizé parodè, kad pritraukti talentus tenka vadovams, neturintiems specialiu igūdžiu ir kvalifikacijos šiai veiklai tinkamai atlikti. Apsirūpinama talentais tokiais pat metodais kaip ir kitu personalu. Ir šiuo atveju tai vyksta nevisiškai tinkama tvarka, daugiau dèmesio skiriant darbuotojo išlaikymo kainai, o itin mažai - talentus motyvuojančiu veiksniu sistemai, kuri labai svarbi skatinant kokybišką ir efektyvu organizacijos darbą.
\end{abstract}

Reikšminiai žodžiai: talentas, gabumai, motyvacija, farmacija, organizacija, personalas, verbavimas. 


\section{Ivadas}

Talentingumo sąvoka šiuolaikiniame moksle interpretuojama ịvairiai. Pavyzdžiui, Grakauskaitè-Karkockienè (2002) talentingumą aiškina taikydama Gardnerio sąvokos interpretaciją (1992) - kad talentas atsiskleidžia per gabumų, intelekto, žinių, motyvacijos ir nuostatų visumą, kuri lemia individo profesinę sėkmę įvairiose srityse (Gardneris, 1992, cit. Grakauskaitè-Karkockienè, 2002). Kai kuriais atvejais talentas aiškinamas kaip gebejjimų atskleidimas, kuris priklauso nuo šeimos, mokyklos ir visuomenès požiūrio ir ịtakos (Grakauskaitė-Karkockienè, 2006; Mönkas ir Ypenburgas, 2003). Mönkas ir Ypenburgas (2003) talentą, pavyzdžiui, priskiria prie gabumų. Tad kai kurie mokslininkai sąvokas „,gabumai“ ir „talentas“ skirtingai interpretuoja, nors dažnai jos abi vartojamos kaip artimos reikšmės žodžiai. Tačiau visi sutinka, kad talentas yra tiesiogiai susijęs su intelektiniais gebejjimais tam tikroje mokslo ar veiklos srityje. Taigi sąvoka „talentingas“ taikoma, kai kalbama apie meno, sporto, muzikos ir kitas sritis, kur pasireiškia ịvairūs išskirtiniai, dominuojantys asmenybės gabumai. Šiame darbe vadovausimès Gagné (2018) sąvoka, kad talentas - tai veikloje išvystyti gabumai. Aktuali šiam straipsniui taip pat yra Feldhuseno (1994) talento sąvoka, kuri akcentuoja, kad gabumus ir talentingumą lemia ịgymiai (genetiškai nulemti gebejimai), ankstyvos gebejjimų apraiškos, gebejimai ir polinkiai, žinios, kūrybiniai gebèjimai, metakognityvūs gebèjimai, motyvacija ir mokymosi stilius.

Žodis „talenta“ lotynų kalboje reiškia polinkị, norą, troškimą. Šumere, Babilone, Graikijoje ir Romoje talentu buvo vadinamas senovinis svorio ir piniginis matavimo vienetas, Biblijoje, Evangelijoje pagal Matą, - kūno ar minčių jèga, kurią Dievas suteikia žmogui tam, kad jis ją dar labiau subrandintų ir sustiprintų.

Jungtinèse Amerikos Valstijose 2013 m. atliktas tyrimas parodè, kad talentingais žmonèmis išsiskiria daugiau nei puse pelningiausių kompanijų TOP50, tarp jų ir esančios pačiose aukščiausiose pozicijose - „Apple“, „Microsoft“ ir „Google“. Remiantis „Adecco Group“ atliktu tyrimu „Tarptautinis talentų konkurencingumo indeksas 2015-2016“, iš 20 konkurencingiausių pasaulio šalių net 18 - Vakarų valstybès. Tačiau Lietuvos valstybinèje 2013-2022 m. švietimo strategijoje žodžio „talentas“ apskritai nèra. Valstybinès studijų, mokslinių tyrimų ir eksperimentinès (socialinès, kultūrinès) 2013-2020 metu plètros programos 2016-2018 metų veiksmų plane keliamas tikslas sukurti gebančiam ir motyvuotam asmeniui palankią aplinką tapti aukštos profesinès kvalifikacijos specialistu, savęs realizavimą derinančiu su valstybès ir visuomenès lūkesčių tenkinimu.

Talentu išlaikymo ir motyvavimo organizacijoje problemą I. Savickienè (2003), UAB „Personalo centro brokeriai“ direktorè, aiškina tuo, kad, didejant aukšto lygio specialistų ir vadybininkų stygiui, organizacijos susiduria ne tik su problema, kaip atrinkti, bet ir kaip pritraukti talentus, kaip pasiekti, kad organizacija būtų laikoma itin pageidautina darbo vieta. Kad talentingų darbuotojų paieškos problema egzistuoja, galima spręsti, atsakius ị klausimą - ar organizacijoje jau dabar dirba geriausi darbuotojai? Ar geriausi darbuotojai neišeina dirbti ị kitas organi- 
zacijas? (http://www.manager.lt)

Siekiant, kad organizacijose būtų kuo daugiau talentingų darbuotojų, personalo atranka jose turi būti atliekama itin atsakingai. Organizacijos personalas nèra tik darbuotojai - tai yra jos sėkmès garantas. Taigi jos rūpestis turètų būti, kaip atsirinkti tik geriausius ir talentingiausius darbuotojus, o šiuo konkrečiu atveju (vykdant atranką ị farmacijos įmonę) - aukšto lygio specialistus - talentus.

Talentingo darbuotojo atranka prasideda anksčiau, nei atsiranda laisva darbo vieta. Todèl svarbu sukurti potencialių darbuotojų rezervą, objektyviai ịvertinant darbo sudètingumą ir aiškiai apibrèžiant, kokių rezultatų naujasis darbuotojas turès pasiekti ir kokias užduotis turès atlikti paskirtas ị tam tikras pareigas. Žinoma, taip pat turi būti ịvertintos ir naujojo darbuotojo asmeninès savybès (Grenčíková, Guščinskienè, Španková, 2017).

Pagrindinè organizacijų problema - kaip rasti, atrinkti geriausią, talentingiausią ir efektyviausią darbuotoją ị laisvą darbo vietą ir jị išlaikyti. Pradedant „talentu medžioklę“, reikia aiškiai numatyti tikslus, uždavinius, veiklos procesą ir metodus. Taip pat svarbu pasirinkti paieškos, atrankos ir motyvavimo metodus bei kitas talentingo personalo atrankos efektyvumą užtikrinančias priemones.

Tyrimo problema. Farmacijos organizacijose daugiausia dirba aukštaji išsilavinimą turintys žmonès (medikai, farmacininkai, vadybininkai, rinkodaros specialistai ir kt.). Kyla problema - kaip sèkmingai atrinkti talentingus darbuotojus ị farmacijos organizacijas Lietuvoje ir kokie yra jų išlaikymo organizacijose veiksniai?

Tyrimo objektas - talentingo personalo atrankos veiksniai.

Tyrimo tikslas - išsiaiškinti ir išanalizuoti pagrindinius veiksnius, skatinančius talentingus darbuotojus dirbti šiuolaikinèje organizacijoje.

\section{Tyrimo uždaviniai:}

1) išsiaiškinti, kas yra talentingas organizacijos personalas;

2) nustatyti, kaip aprūpinti organizaciją talentingu personalu;

3) rasti būdų, kuriais būtų galima geriau apsirūpinti talentingais darbuotojais Lietuvos farmacijos organizacijose.

Tyrimo metodai ir metodologija: teorinès medžiagos lyginamoji analizè ir sintezė; apklausa anketuojant farmacijos organizacijų administracijos darbuotojus.

Straipsnyje pateikiamos ir analizuojamos talento, kompetencijos sąvokų sampratos ir jų samplaika, orientavimo ir motyvavimo veiksnių svarba siekiant ilgą laiką išlaikyti talentus.

Remiantis moksliniais straipsniais sudaryta ir pateikta farmacijos organizacijų administracijos darbuotojams (vadovams ir specialistams) elektroninė anketa. Surinkti duomenys turi padèti nustatyti talentų svarbą, apsirūpinimo jais būdus ir jų išlaikymo organizacijoje aspektus.

Anketavimo rezultatai padejjo išskirti problemas, su kuriomis susiduria farmacijos organizacijos apsirūpindamos talentais ir juos išlaikydamos, ir suformuluoti pasiūlymus, kaip galima būtų pagerinti situaciją - aktyvinti apsirūpinimo talentais procesą ịtraukiant kuo daugiau motyvuojančių veiksnių, gerinančių vykdomų veiklų kokybę. 


\section{Organizacijos apsirūpinimas talentingu personalu}

Dabartinėms organizacijoms apsirūpinimas talentingu personalu yra ilgalaikis ir tikslingas procesas, paremtas tam tikrais principais ir standartais, tokiais kitaip bendradarbiavimas ir ịsipareigojimas samdyti, išsaugoti ir ugdyti talentus organizacijos sėkmei užtikrinti (HRfocus, 2008 kovas).

Specialiojoje literatūroje teigiama, kad įmonès pasiektų užsibrèžtą sėkmę, reikalingas tikslas ir nuoseklus personalo vadybos veiksmų planavimas. J. A. F. Stoner, Jatautaitè, Kazimianec (2018) ir kiti (1999) pateikia žmoniu ištekliu valdymo proceso organizacijoje schemą (1 pav.).

\begin{tabular}{|c|}
\hline $\begin{array}{l}\text { 1 etapas } \\
\text { Nustatyti talentingo asmens poreiki darbo vietai }\end{array}$ \\
\hline $\begin{array}{c}\text { 2 etapas } \\
\text { Sutvarkyti darbo vietos dokumentus }\end{array}$ \\
\hline $\begin{array}{l}3 \text { etapas } \\
\text { Nustatyti verbavimo kanalus }\end{array}$ \\
\hline $\begin{array}{c}\text { 4 etapas } \\
\text { Sudaryti verbavimo turini ir priemones }\end{array}$ \\
\hline $\begin{array}{c}\mathbf{5} \text { etapas } \\
\text { Nustatyti atrankos kriterijus }\end{array}$ \\
\hline $\begin{array}{c}\text { 6 etapas } \\
\text { Talentingų kandidatų pasirinkimas }\end{array}$ \\
\hline $\begin{array}{l}\text { 7 etapas } \\
\text { Atsirinkti ir patikrinti geriausius kandidatus i darbo vietą }\end{array}$ \\
\hline $\begin{array}{c}\text { } 8 \text { etapas } \\
\begin{array}{c}\text { Galutinis kandidatų ịvertinimas, pagal pasiruoštą darbo } \\
\text { aprašymą, pasirenkami geriausi kandidatai }\end{array}\end{array}$ \\
\hline $\begin{array}{c}\text { 9 etapas } \\
\text { Patikrinti pasirinkto geriausio kandidato kvalifikaciją }\end{array}$ \\
\hline $\begin{array}{l}\text { 10 etapas } \\
\text { Su sėkmingai pasirodžiusiu kandidatu tartis dèl apmokèjimo, } \\
\text { priedų, tęsti abipusę sutartị dèl ịdarbinimo pirma } \\
\text { atsižvelgiant } \mathfrak{i} \text { kompanijos, po to }-\mathfrak{i} \text { kandidato interesus }\end{array}$ \\
\hline $\begin{array}{c}11 \text { etapas } \\
\text { Patvirtinti pasirinkimą samda }\end{array}$ \\
\hline
\end{tabular}

1 pav. Talentingo personalo apsirūpinimo etapai

Šaltinis: D. D. Dubois, W. J. Rothwell, Competency-based HR.

Management (2004) 
Žmonių išteklių, kitaip - darbuotojų poreikio, planavimas - tai planų, kaip užpildyti atsirandančias laisvas darbo vietas, sudarymo procesas, grindžiamas ateityje atsirasiančių laisvų darbo vietų prognoze ir sprendimu, ar išorès ir vidaus kandidatai bus verbuojami ị šias darbo vietas (Dessler, 2001).

Tradicinio planavimo ypatumas yra tai, kad daroma prielaida, jog ateitis bus tokia kaip ir praeitis ir kad tam tikra žmonių grupè atliks tiksliai numatytą darbą. Kompetencija grindžiant darbuotojų verbavimą ir atranką daroma prielaida, kad praeities elgesys gali padèti numatyti elgesị ateityje panašiose situacijose (Goldstein, Davison, 1998).

Talentų vadyboje turi būti numatomi tikslai, metodai, laukiami rezultatai, jų pasiekimo laikotarpis (terminas), vertinimas, prisitaikymą prie kintančios aplinkos lengvinančios priemonès ir eigos kontrolè. Tradicinio personalo valdymo atveju vienu metu naudojami keletas teoriškai nustatytų metodų, pagal kuriuos planuojama veikla. Metodai talentų vadyboje - tai tik priemoné, padedanti planuoti (Dubois, 2004).

Talentų išteklių planavimas - tai nuoseklių veiklų visuma. D. Dubois (2004) pateikia 11 etapų apsirūpinimo talentais, kompetentingais darbuotojais organizacijoje schemą (1 pav.).

Verbavimas - tai procesas, kurio metu surandami ir priviliojami ị organizaciją, laisvas darbo vietas, potencialūs kandidatai. Šios veiklos rezultatas - tam tikras skaičius kandidatų, iš kurių bus atrinktas ir pasamdytas reikalingas darbuotojas (Bakanauskienè, 2002).

D. Dubois (2004) išskiria 4 tradicinio personalo verbavimo etapus:

1. Laisvos darbo vietos nustatymas - galimi du variantai: planuoti darbuotojų ateities poreikị arba nustatyti faktinį darbuotojo trūkumą (kai jau yra laisva darbo vieta).

2. Darbo vietos ir reikalingu igūdžiu aprašymas - darbo aprašymas, užduočių detalizavimas tam, kad būtų lengviau sudaryti reikiamų kandidatų savybių sąrašą ir atlikti atranką.

3. Verbavimo šaltiniu pasirinkimas - vidinių ar išorinių šaltinių pasirinkimas atliekant kandidatų paiešką.

4. Pasirenkamas veiksmingiausias büdas pritraukti atsirinktus kandidatus organizacija turi rasti būdą, kaip įtikinti tinkamą darbuotoją, kad tai geriausia vieta dirbti.

G. Dessler (2001) i verbavimo procesą įtraukia: 1) personalo poreikio prognozę; 2) kandidatų pasiūlos prognozę ir 3) verbavimo šaltinių pasirinkimą.

Remiantis A. Sakalu (1998), ši procesą sudaro 4 etapai:

1) Verbavimo dokumentų paruošimas/pateikimas.

2) Dokumentų vertinimas, pirminè atranka pagal formalius duomenis.

3) Atrinktų kandidatų pirminè kontaktinè atranka.

4) Galutinè atranka.

Daugelis autorių, kurie analizuoja tradicinę ir talentais paremtą personalo 
paiešką, pabrèžia - talentingo personalo paieška skiriasi nuo tradicinès tuo, kad, pradedant planuoti ịprastinę paiešką, dėmesys skiriamas išlaidoms - kiek tai kainuos, ir priešingai, planuojant talentų paiešką, galvojama, kokiq naudq atneš naujas žmogus įmonei.

Siekiant verbuoti talentus, D. Dubois (2004) teigia, pirmiausia būtina nustatyti talentingo darbuotojo poreiki (1 pav.), kai organizacijos vadovas ar personalo skyrius nusprendžia, kad reikalingas talentingas darbuotojas ir pradeda jo ieškoti. Šis poreikis turi būti pagrịstas, tikslus ir detalizuotas, atsižvelgiant ị organizacijos struktūrą, kultūrą, finansines galimybes ir kita.

Labai svarbu, kad darbuotojas būtų parinktas atsižvelgiant ị konkrečios darbo vietos reikalavimus. Nèra blogų darbuotojų, yra tik dirbantys ne savo darbą. Humanistine personalo vadybos koncepcija, kuri yra pagrịsta šiuo požiūriu, teigia, kad jei darbuotojas klaidą padaro nepiktavališkai, dèl to kaltas ne jis, o darbdavys, i darbo vietą netinkamai parinkęs darbuotoją, neịvertinęs jo gebėjimų, siekių, asmeninių savybių (http://verslas.banga.lt).

Toliau planuojant talentų verbavimą, turi būti parengiamas laisvos darbo vietos aprašymas (1 pav.). Darbo aprašymas - tai rašytinis dokumentas, kuriame nurodyta, ką turi daryti tam tikrą darbą dirbantis asmuo, kaip ir kokiomis sąlygomis reikia atlikti darbą (Dubois, 2004). Darbo analizé - tai procedūra, kuri skirta darbų pobūdžiui ir žmonių, kurie turètų būti pasamdyti jiems atlikti, savybẻms apibrěžti. Atliekant tokią analizę sutelkiama informacija apie pagrindines darbo funkcijas, veiklos rūšis ir viso darbo esmę (Dessler, 2001).

G. Dessler (2001) darbo aprašyme išskiria dvi dalis: darbo specifikos aprašymą - dali, kurioje išvardijamos darbui patenkinamai atlikti reikalingos žinios, gebejjimai ir igūdžiai, ir darbo identifikavimo dalị, kurioje nurodomas pareigybès (darbo) pavadinimas.

D. Dubois (2004) siūlo tokią analizę atlikti pagal šiuos kriterijus:

- Darbo apimtis, aktyvumas, trukmè, užduotys, reikalaujančios darbuotojo kompetencijos.

- Kompetencijos, talento svarba, kad darbas būtų atliktas sėkmingai.

- Asmeninès kompetencijos, talento požymiai, kurie padètų nustatyti, ar žmogus tikrai bus perspektyvus (asmeninės savybès).

Darbo analizę I. Bakanauskienė (2002) ịvardija kaip personalo valdymo veiklą, apimančią informacijos apie darbus rinkimą, ịvertinimą ir organizavimą. Kad būtu galima sẻkmingai atlikti darbo analizę, ji siūlo nustatyti darbo analizès panaudojimo tikslus, pvz., planuoti reikalingus žmonių išteklius, išsiaiškinti, ar organizacijoje yra vidinè pasiūla; ịvardyti analizuojamus darbus, pvz., darbo apimties, ìvairovès, trukmès aprašymas ir kita; surinkti duomenis apie darbus, pvz., nustatyti metodus, kuriuos tikslinga pasirinkti, ịvertinant laiką, sąnaudas, tikslumą.

Darbo aprašymas reikalingas, kad būtų lengviau nuspręsti, kokius žmones reikia verbuoti, atrinkti, o vèliau ir kaip juos motyvuoti.

Remiantis D. Dubois (2004), siekiant pritraukti ị organizaciją talentą, reika- 
lingas 3-ias etapas - nustatyti verbavimo šaltinius (1 pav.).

Norėdami rasti gerų darbuotojų, ypač talentų, ị laisvas darbo vietas, darbdaviai turi parodyti vis daugiau iniciatyvos ir išradingumo. Jau nebepakanka įdèti skelbimą apie laisvą darbo vietą ị vietos laikraštị ir laukti kandidatų antplūdžio. Talentingo personalo verbavimas reikalauja vis daugiau pastangų.

G. Dessler (2001) teigia, kad, atsakius ị klausimą, kiek reikès darbuotojų, reikia atlikti išorès ir vidaus kandidatų pasiūlos prognozę. I. Bakanauskienè (2002) pažymi, kad vidiniai verbavimo šaltiniai yra darbo skelbimai, asmens bylos, darbuotojų pasikeitimo diagramos, kompiuterizuotos informacinès sistemos ir kt. Šiuos šaltinius palankiau pasirinkti dėl kelių priežasčių - dèl paprastumo, lengvesnès adaptacijos, mažesnès personalo tekamumo tikimybės. Prie išorinių verbavimo šaltinių ji priskiria kompiuterines duomenų bazes, laikinus darbuotojus, stažuotes, „galvų medžioklę“ (Bakanauskienè, 2002). V. Misevičiaus (2002) internete publikuotame straipsnyje „Personalo atrankos būdai“ minimi aštuoni verbavimo šaltiniai:

1) Naudojimasis vidiniais kompanijos resursais.

2) Atranka naudojantis esamų darbuotojų rekomendacijomis.

3) Skelbimai laikraščiuose.

4) Paieška universitetuose.

5) İdarbinimo agentūrų paslaugos.

6) Dalyvavimas karjeros dienose.

7) Internetiniai skelbimai ir duomenų bazès.

8) Valstybinių darbo biržų paslaugos.

D. Dubois (2004), nagrinėjęs kompetencija paremtų žmogiškujjų išteklių verbavimo procesą, teigia, jog organizacija, nustačiusi talento poreikị ir padariusi darbo analizę, renkasi verbavimo šaltinius. Talentams verbuoti ji gali naudoti visus verbavimo šaltinius, kaip ir tradiciniame modelyje, tačiau turi iš anksto įvertinti, kurie šaltiniai yra prioritetiniai, o kuriuos naudoti būtų visiškai neefektyvu. Rasti darbuotoją nepakanka. Reikia jị pritraukti ị konkrečią organizaciją.

\section{Tyrimo turinys ir eiga}

Tyrimui atlikti buvo pasirinktos Lietuvos farmacijos organizacijos, kuriose didžiają personalo dali sudaro aukštajị išsilavinimą turintys žmonès, aukštos kompetencijos ir talentus atskleidę darbuotojai. Tyrimas buvo atliekamas $2018 \mathrm{~m}$. balandžio mènesị, pateikus anketas organizacijų vadovams ir administracijos darbuotojams. Klausimai buvo pateikti internetine anketa.

Iš viso buvo surinkta 30 anketų. Farmacijos organizacijos labai nenoriai dalijosi duomenimis apie apsirūpinimo darbuotojais veiklas: personalo verbavimą, motyvavimą. I anketos klausimus delsè atsakyti. $31 \%$ respondentų užpildẻ anketas, $65 \%$ visų respondentų, kuriems buvo siųsta anketa, jos neužpilde ir duomenų nepateikè. $4 \%$ pranešè, kad tai - organizacijos konfidenciali informacija. 
Šio tyrimo patikimumui padidinti farmacijos organizacijos buvo pasirinktos atsitiktinai. Darbuotojams, kurie buvo anketuojami, išsamiai paaiškinta, kam tyrimo metu bus naudojami duomenys, kad anketos ir duomenys bus anoniminiai, struktūrizuoti, apibendrinti ir niekur kitur, išskyrus ši darbą, nenaudojami.

\section{Tyrimo metodas ir eiga}

Taikant tyrimo metodologiją atliktas kiekybinis tyrimas - anketinè apklausa elektroniniu paštu. R. R. Powell ir L. S. Connaway (2004) apklausos metodą vertina kaip vieną dažniausiai taikomų duomenų rinkimo metodų. Tyrimui atlikti buvo sudaryta anketa.

Tyrimas buvo atliktas $2018 \mathrm{~m}$. balandžio mèn. - juo buvo siekiama užfiksuoti tik tam tikrą situaciją konkrečiu laiku. Kitaip šie tyrimai dar yra vadinami skerspjūvio arba momentiniais (Klebanskaja, 2006). Pagal iškeltą tikslą atliktas aprašomasis tyrimas. Anketoje respondentų buvo prašoma atsakyti ị klausimus apie:

- lojalumą darbovietèms;

- talento savybes, svarbą organizacijai;

- darbuotojus motyvuojančius veiksnius;

- respondentą (jo asmeninè informacija - pareigos, darbo patirtis).

Po to buvo kaupiami ir grupuojami duomenys pagal suformuluotus uždavinius. Informacijos šaltiniai suskirstyti į vadovaujantį personalą (vadovus) ir administracijos darbuotojus. Visi respondentai anketas pildè anonimiškai.

Toliau surinkta informacija buvo analizuojama remiantis atrinkta teorine medžiaga.

Klausimai buvo sudaryti pasirinktinai iš duotų variantų - uždari ir atviri. I pastaruosius respondentai atsakymą turejo pateikti patys (1 ir 12 klausimai). Dalis klausimų buvo uždari, tačiau respondentai turejjo galimybę įrašyti ir savo variantą $(1,2,3,8,9,11,12,13,20,21$ klausimai). Atsakydami ị 20 ir 21 kausimus respondentai vertino pasirinkimus skaleje nuo 1 iki 10, atsakydami į 8, 13, 15, 19 ir 22 klausimus - galejjo žymėti visus tinkamus variantus.

$8,10,13,19,20,21$ klausimai buvo parengti remiantis vadybos autoriu (D. Dubois, 2004; R. White, D. C. McClelland, 2002, N. Nohria ir kt.) talentų vadybos veiklų aprašymais.

Imtis pasirinkta netikimybine, t. y. respondentai buvo atrinkti atsitiktinai.

\section{Respondentai}

Tiriamųu grupę sudarė 12 farmacijos organizacijų darbuotojai, sutikę teikti duomenis tyrimui:

8 vidutinio ir aukščiausio lygio vadovai, bendrasavininkiai;

22 administracijos darbuotojai (finansininkai, administratoriai, vadybininkai, personalo skyriaus darbuotojai). 
Daugiausia respondentų - $57 \%$ - buvo uždarujų akcinių bendrovių, $37 \%-$ atstovybių, po $3 \%$ - individualios ir akcinès bendrovès darbuotojai. Daugiausia apklaustų respondentų buvo administracijos darbuotojai, specialistai - $68 \%$. Detalesni pasiskirstymo rezultatai pateikti 2 paveiksle.

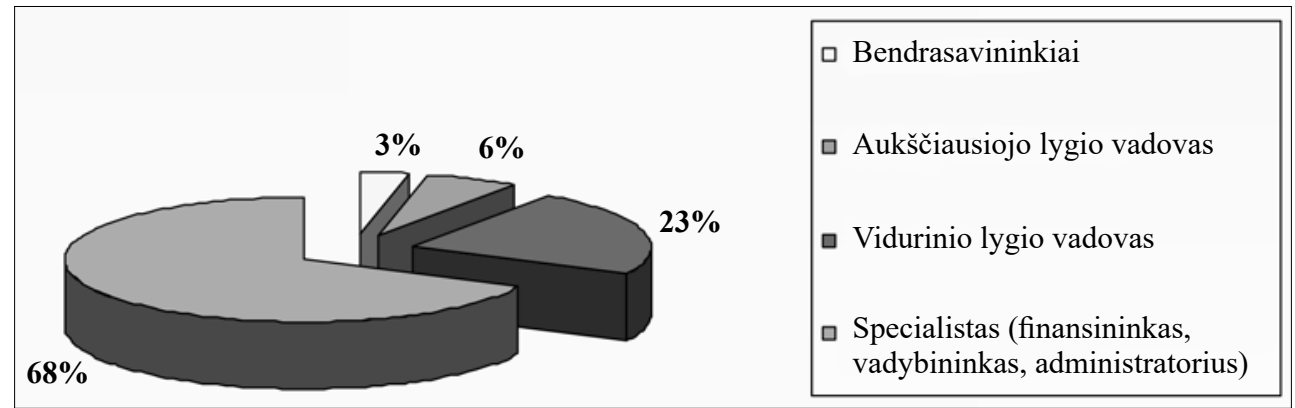

2 pav. Respondentų pasiskirstymas pagal statusą organizacijoje, \%

Farmacijos organizacijose buvo apklausta 20 moterų ir 10 vyrų. Visi respondentai turejo aukštajj išsilavinimą, labiausiai paplitęs - medicina -12 , vadyba -8 , verslo administravimas -5 , finansai -3 , provizorių mokslas -2 , sociologija -2 , organizacinè psichologija -1 . Trys respondentai yra baigę 2 aukštąsias mokyklas.

Daugelis - $74 \%$ - darbuotojų vadovus vertina kaip labai talentingus, $10 \%$ - kaip talentingus, $16 \%$ darbuotojų negali įvertinti arba nežino vadovo talentingumo.

5 paveiksle matyti, kad pagal amžių daugiausia respondentų buvo 26-30 metų farmacijos organizacijų administracijos darbuotojai (3 vadybininkai, 2 medikai ir po 2 verslo administravimo ir sociologijos specialistus - $30 \%$ ).

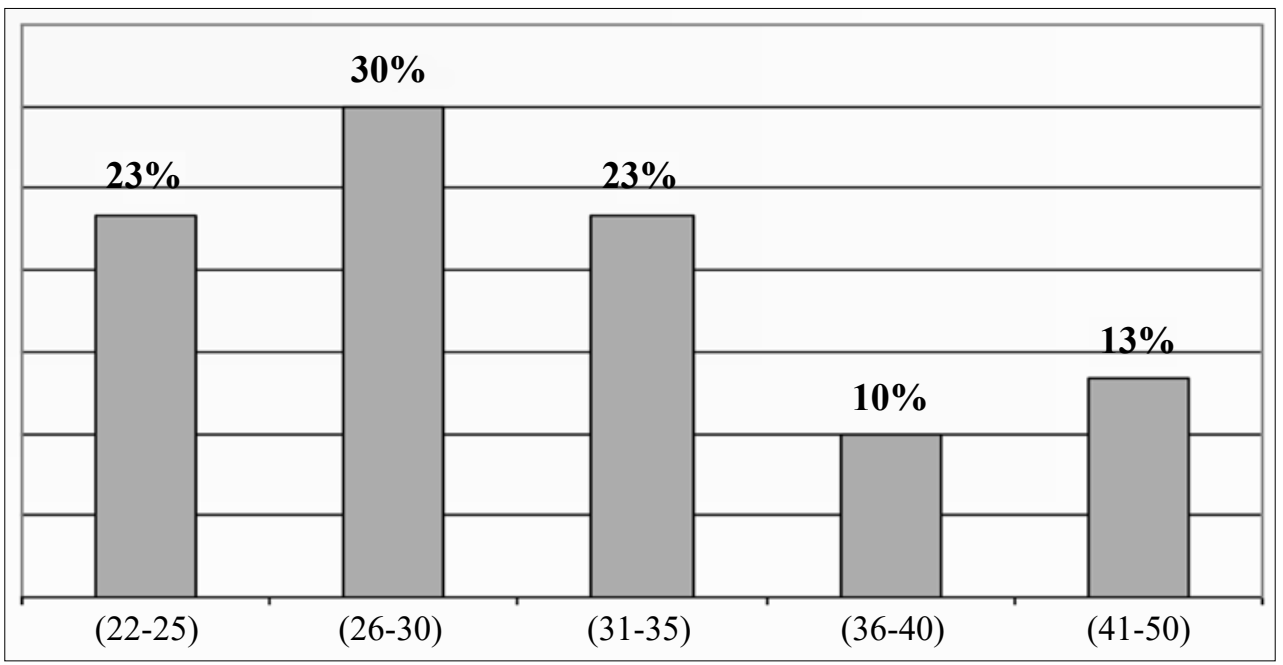

3 pav. Respondentų pasiskirstymas pagal amžių, \% 
Dauguma apklaustų farmacijos organizacijų pagal dirbančių žmonių skaičių patenka ị smulkių ir vidutinių organizacijų grupę. Lietuvos Respublikos smulkaus ir vidutinio verslo ịstatyme (Nr. IX-1142) nurodyta, kad mikroorganizacija yra tokia organizacija, kurioje dirba mažiau nei 10 darbuotojų, maža organizacija - kurioje dirba mažiau nei 50 darbuotojų, vidutinè organizacija - kurioje dirba mažiau kaip 250 darbuotojų, didelè organizacija - kuri turi daugiau nei 250 darbuotojų. Visos organizacijos turi būti savarankiškos. Pagal anketavimo rezultatus, dauguma apklaustų respondentų dirbo mažose (73 \%) arba mikro- (17\%) farmacijos organizacijose.

\section{Anketavimo rezultatų analizė}

Tyrimo metu buvo išsiaiškinta respondentų nuomonė, kokių savybių turinčius darbuotojus daugelis laiko talentingais, ir išskirtos svarbiausios respondentu įvardytos savybès, apibrèžiančios talentą.

Visi respondentai mano, kad pagrindinè talento savybè - gebėjimas sékmingai atlikti darba - glaudžiai susijusi tiek su talentu, tiek su kompetencija (4 pav.). Nuo 80 iki 90 \% respondentų įvardija šias ryškiausias talento savybes:

- specifines asmenines savybes, padedančias sėkmingai atlikti darbą;

- gebejjimą priimti tikslius sprendimus;

- polinkị atskirti sékmingas ir nesėkmingas situacijas ir sėkmingai jose veikti.

Respondentų nuomone, nuo 60 iki $79 \%$ talento savybes ịvardijo daugiau igimtines arba tikslingai išsiugdomas. Tai:

- savimotyvacija veikti;

- gebėjimas lengvai prisitaikyti prie naujovių;

- komunikabilumas.

Nuo 40 iki $59 \%$ respondentu išvardino talento savybes, kurios yra ịimtos arba ilgalaikèmis ir tikslingomis pastangomis išsiugdomos. Tai:

- logika;

- racionalumas;

- draugiškumas;

- puiki atmintis;

- linksmumas.

Respondentų nuomone, drąsumas, azartiškumas ir uždarumas nėra tokios reikšmingos savybès. Jas ịvardijo nuo 3 iki $25 \%$ respondentų. 


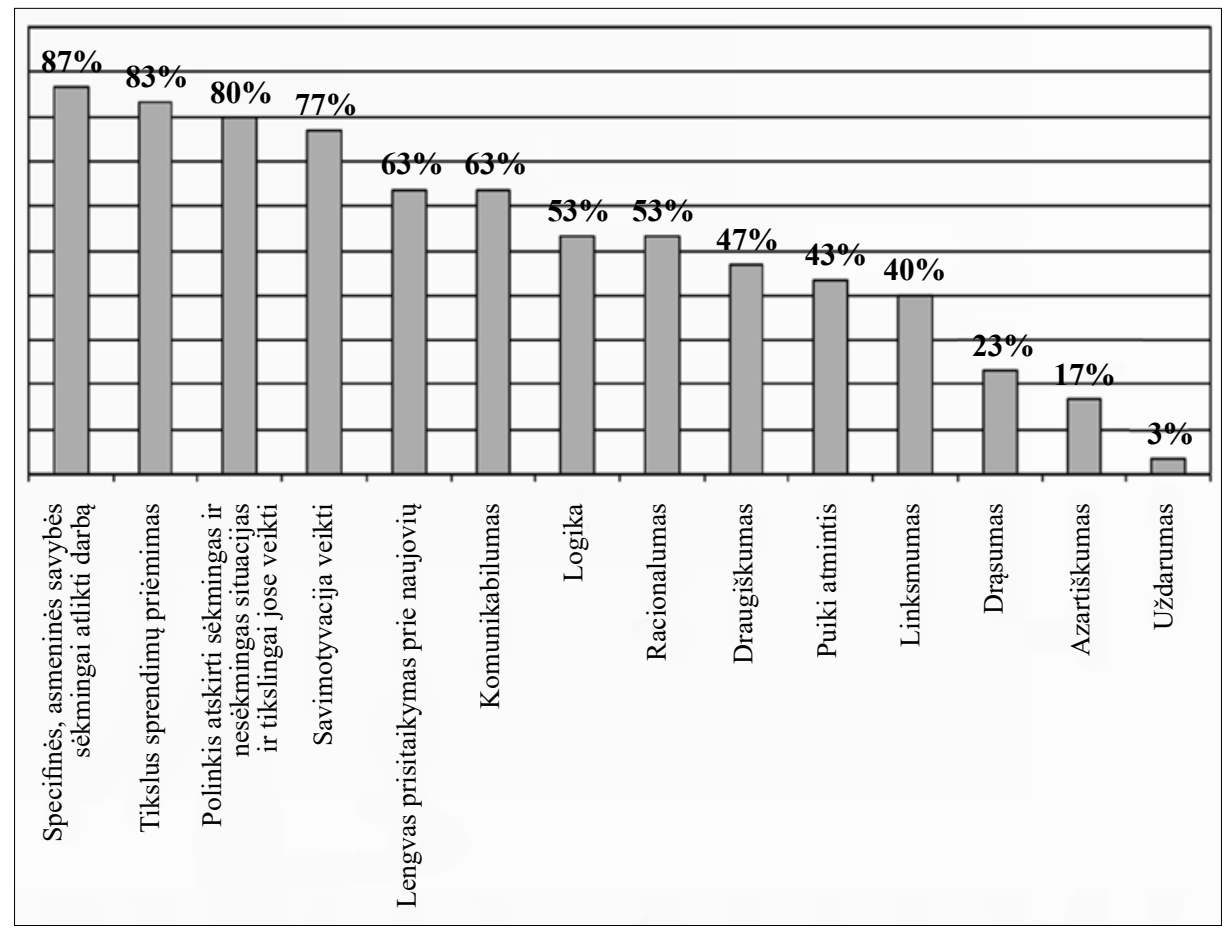

4 pav. Respondentų nuomonė apie talento savybes, \%

Remiantis anketinès apklausos duomenimis, didžioji dalis, net $59 \%$, respondentų mano, kad farmacijos organizacijose turi dirbti tik talentingi darbuotojai. $32 \%$ teigia, kad pakanka, jei talentingas yra organizacijos vadovas ir iki $10 \%$ visų darbuotojų. Tačiau yra manančių ir kitaip $-6 \%$ respondentų teigia, kad talentingas turi būti tik organizacijos vadovas, ir $3 \%-$ kad tokie turi būti tik darbuotojai (5 pav.).

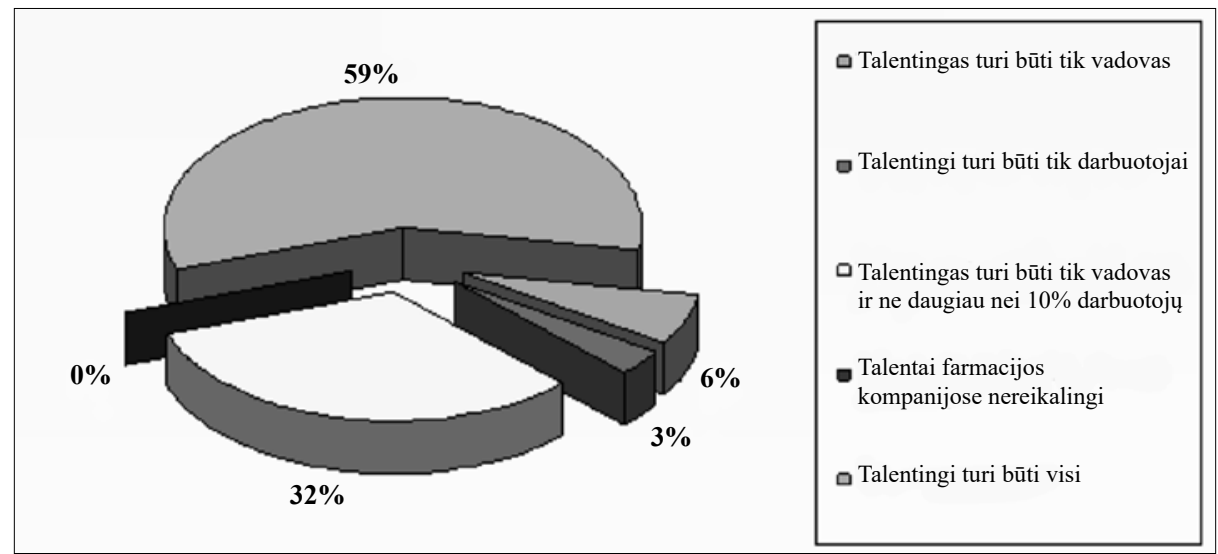

5 pav. Respondentų nuomone, talentų svarba farmacijos kompanijose, \% 
Norint patikrinti respondentų atsakymų patikimumą buvo pateiktas klausimas apie esamą talentų skaičių (procentine išraiška) jų organizacijoje. Daugelis respondentu $(40 \%)$ teige, jog beveik pusė jų organizacijos personalo yra talentai, $37 \%$ respondentų teigè, kad talentingi - visi (tačiau yra tikimybè, kad šis atsakymas buvo žymimas dèl solidarumo, kadangi, neturint kompetencijos, ganėtinai sunku vertinti kito žmogaus talentą). Buvo ir skirtingai manančių: vieni teigè, kad talentingi yra tik jų organizacijos vadovai $-3 \%$ respondentų, ir $17 \%$ - jog talentai jų organizacijoje sudaro tik iki $10 \%$ (8 pav.).

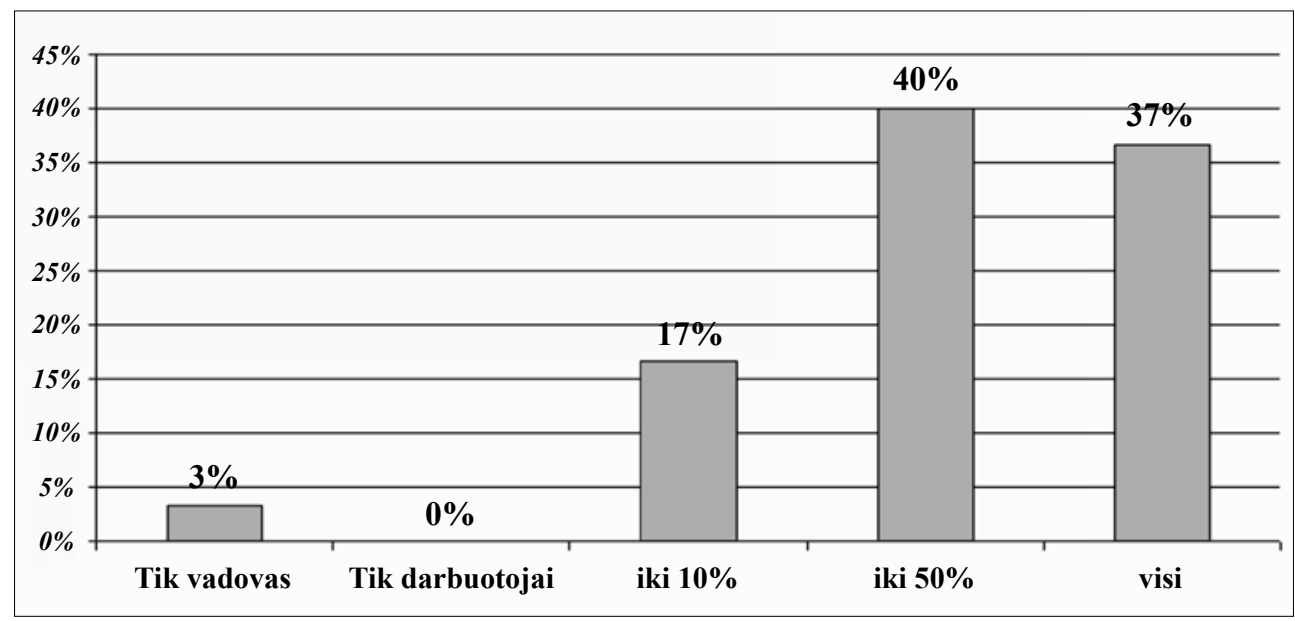

6 pav. Respondentų nuomonè apie talentų skaičių farmacijos organizacijose, \%

Apsirūpinimas talentingu personalu reikalauja pastangų. Vadybos mokslo atstovų nuomone, tuo būtina rūpintis ir stebėti darbuotojų judèjimą kiekvienoje organizacijoje, planuoti darbuotojų, ypač talentingų, poreikị, orientuojantis i ateitị. 7 paveiksle „Respondentų nuomonè apie personalo poreikio peržiūros periodiškumą“ matyti, kad daugiau nei $75 \%$ organizacijų personalo dinamiką ir darbuotojų poreikị peržiūri:

$53 \%$ - kas pusę metų;

$23 \%$ - kas ketvirtį;

$23 \%$ respondentų teigè manantys, kad jų organizacijose darbuotojų poreikis nustatomas tik atsiradus laisvai darbo vietai ir organizacija išskirtinio dèmesio personalo valdymui neteikia. 


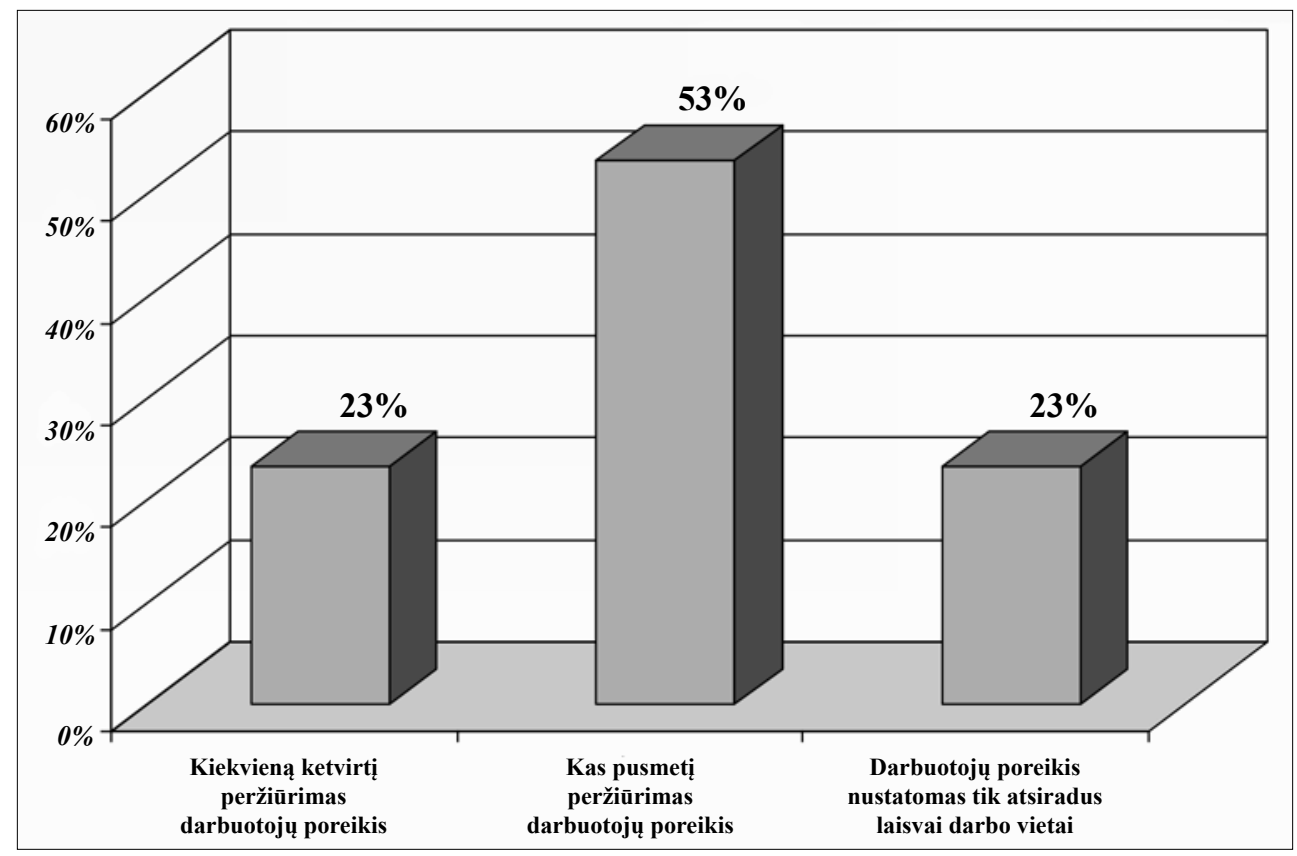

7 pav. Respondentų nuomonė apie personalo poreikio peržiūros periodiškumą

Kaip vadybos mokslo atstovai teigia, talentų paiešką ir atranką turi (arba gali) vykdyti vadovai, jei jie ypač gerai susipažinę su šio darbo specifika, arba šios darbo srities specialistai. Respondentų nuomone (88 \%), talentingus darbuotojus $i$ farmacijos organizacijas verbuoja, atrenka vadovai ir darbo srities specialistai. $7 \%$ teigè nežinantys, o $5 \%$ ị klausimą neatsakè. Analizuojant duomenis pastebèta, kad iš 9 anketuotų vadovų 2 yra medikai, 1 - medikas/ verslo administravimo specialistas, 2 - ekonomistai, 1 - vadybininkas ir 1 - baigęs organizacinès psichologijos specialybę.

Susumavus atsakymų i 11 klausimą rezultatus buvo nustatyta, kad tik $17 \%$ organizacijų turi personalo skyrių, kuris rūpinasi savo personalo judejjimu: verbavimu, atranka, samda ir kt. $13 \%$, respondentų teigimu, šie darbai atitenka skyriui, kuriam naujas darbuotojas yra reikalingas. $61 \%$ teige, kad ši darbą atlieka kompanijų vadovai, $74 \%$ - vadovai su vadovaujančiu personalu (srities specialistais), ir tik $4 \%$ - kad naudojasi nepriklausomų organizacijų paslaugomis - įdarbinimo agentūromis (8 pav.). 


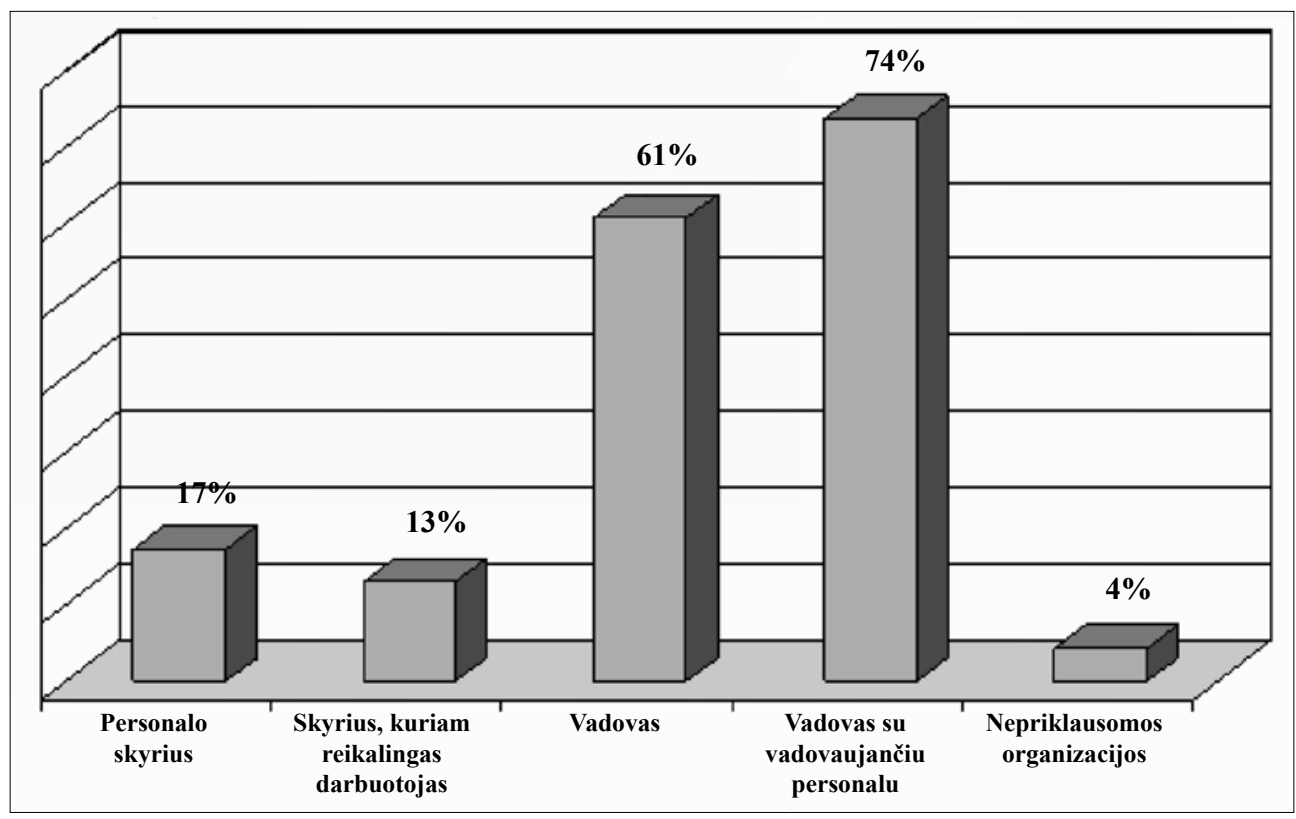

8 pav. Respondentų nuomonè apie verbavimo, atrankos proceso dalyvius, $\%$

8 paveiksle matyti, kad daugiausia verbavimo veiklų apsiima vadovas (61\%) ir vadovas su vadovaujančiu personalu (74 \%). Dviejų atsakymų žymejjimą respondentai aiškina tuo, kad vadovas darbuotojo apsirūpinimo procese visą laiką dalyvauja vienas, kai pakanka kompetencijos, darbo praktikos žinių, ar pasitelkia darbo srities specialistus, kurie padeda atlikti apsirūpinimo darbuotojais veiklas.

Iš pateiktų duomenų ( 9 pav.) galima daryti išvadą, kad farmacijos organizacijos dažniausiai neturi apsirūpinimo talentingu personalu sistemos. Dauguma organizacijų, besirenkančių talentingus darbuotojus, nekonkretina veiklų, kuriomis remsis ieškodamos kandidatų, o vèliau ir atrinkdamos juos, eigos. Taip pat nepopuliaru, renkantis darbuotoją, atrankos metu pateikti testus, nustatančius darbuotojo žinių, kompetencijos, talentingumo lygị.

Vertinant pateiktą respondentų eiliškumą galima pastebėti, kad dažnai organizacijose pageidaujamos kandidato savybès yra sukonkretinamos tik po tiesioginio interviu. Retai pirmą atranką jos atlieka telefonu.

Respondentų teigimu, itin svarbus aspektas - nustatyti naujam darbuotojui bandomajị laikotarpị, kurio metu būtų galima ịvertinti, ar darbuotojas yra perspektyvus ir talentingas, ar jam priimtinos organizacijos vertybès, tikslai, ir tik po bandomojo laikotarpio nuspręsti, pratęsti darbo sutartị ar ne.

Detalesni duomenys pateikti 9 pav. šia tvarka:

Veiklos aprašymas (balta).

Veiklos eiliškumas (geltona).

Respondentų, pasirinkusių veiksmą pagal eiliškumą, skaičius (žalia). 
Pvz.: interviu telefonu kaip pirmą veiklą, atliekant darbuotojų verbavimą, nurodo 7 respondentai, kaip trečią veiklą -3 respondentai.

\begin{tabular}{|c|c|c|c|c|c|c|c|c|c|c|c|c|c|c|c|c|c|c|c|c|c|}
\hline $\begin{array}{c}\text { Paren- } \\
\text { giamas } \\
\text { darbo } \\
\text { vietos } \\
\text { apra- } \\
\text { šymas }\end{array}$ & & $\begin{array}{l}\text { Sukon } \\
\text { tinam } \\
\text { ieškor } \\
\text { larbuo } \\
\text { Ismen } \\
\text { savyb }\end{array}$ & $\begin{array}{l}\text { kre- } \\
\text { nos } \\
\text { mo } \\
\text { otojo } \\
\text { hinès } \\
\text { bès }\end{array}$ & & $\begin{array}{l}\text { erv } \\
\text { tele } \\
\text { fon }\end{array}$ & & $\begin{array}{r}\text { Tiesic } \\
\text { inte }\end{array}$ & $\begin{array}{l}\text { ogin } \\
\text { erviu }\end{array}$ & & & $\begin{array}{l}\text { intrinis } \\
\text { terviu }\end{array}$ & $\begin{array}{c}\text { Testavi- } \\
\text { mas }\end{array}$ & & rtinime & & & $\begin{array}{l}\text { kome } \\
\text { dacijy } \\
\text { rinim }\end{array}$ & & \multicolumn{3}{|c|}{$\begin{array}{l}\text { Darbuotojui } \\
\text { suteikiamas } \\
\text { bandomasis } \\
\text { laikotarpis }\end{array}$} \\
\hline 1 & 1 & \begin{tabular}{|l|l|}
2 & 3
\end{tabular} & 4 & 6 & 1 & 1 & 12 & 3 & 4 & \begin{tabular}{l|l}
2 & 3
\end{tabular} & 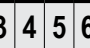 & \begin{tabular}{|l|l|l|l|}
2 & 3 & 4 & 5
\end{tabular} & $\begin{array}{ll}3 & 4\end{array}$ & 456 & \begin{tabular}{|l|l|}
6 & 7
\end{tabular} & 3 & \begin{tabular}{l|l}
4 & 5
\end{tabular} & 7 & \begin{tabular}{|l|l|}
3 & 4 \\
\end{tabular} & \begin{tabular}{|l|l|l|}
5 & 6 & 7 \\
\end{tabular} & \begin{tabular}{|l|l|}
8 & 9 \\
\end{tabular} \\
\hline 10 & 10 & \begin{tabular}{l|l}
8 & 1
\end{tabular} & 1 & 1 & 7 & & 49 & 3 & 4 & 79 & $\begin{array}{llll}9 & 2 & 4 & 2\end{array}$ & \begin{tabular}{|l|l|l|l}
1 & 4 & 2 & 1
\end{tabular} & 36 & 36 & 61 & 2 & $\begin{array}{ll}5 & 7\end{array}$ & 1 & 122 & \begin{tabular}{l|l|l|}
6 & 5 & 4
\end{tabular} & $\begin{array}{lll}4 & 1\end{array}$ \\
\hline 10 & & 17 & & & 10 & & 2 & 20 & & & 24 & 8 & & 19 & & & 10 & & & 23 & \\
\hline
\end{tabular}

9 pav. Respondentų nuomonė apie apsirūpinimo talentais eiliškumą Lietuvos farmacijos organizacijose

Naudojantis šiais duomenimis, vertinant eiliškumą ir pasikartojimų dažnị, galima teigti, kad farmacijos organizacijos, rinkdamosi naują darbuotoją, atlieka iki 7 veiksmų:

1) Parengia darbo vietos aprašymą (1-10 balų).

2) Organizuoja tiesioginị interviu (2-9 balai).

3) Parengia darbuotojo savybių, reikalingų darbo funkcijoms atlikti, aprašymą ( $2-8$ balai).

4) Kviečia respondentus į antrą interviu (3-9 balai).

5) Vertina kandidatus (4-6 balai).

6) Tikrina rekomendacijas (5-7 balai).

7) Nustato bandomaji laikotarpi atrinktam kandidatui (5-6 balai).

9 klausimas padèjo išsiaiškinti, ar farmacijos organizacijose talentams pritraukti naudojami kitokie / ivvairesni metodai, kitokia atranka. Dauguma respondentų (76\%) atsake, kad tiek kompetentingų, tiek kitu darbuotojų verbavimo ir atrankos metodai yra tokie pat, $15 \%$ teigè, kad naudoja kitokius metodus, tačiau jų neįvardijo, $9 \%$ respondentų teigè, jog nežino, ar organizacijose yra diferencijuojami talentų ir kitų darbuotojų paieškos ir atrankos metodai.

Siekiant patvirtinti talentingų darbuotojų verbavimui naudojamus metodus buvo atlikta analizè, pateikiant parengtus atsakymus (8 klausimas), kokiais būdais farmacijos organizacijose ieškoma darbuotojų ir talentų.

Iš gautų atsakymų 10 paveiksle matyti, kad daugumą (55\%) personalo paieškos šaltinių sudare du verbavimo šaltiniai: paieška remiantis pažistamų rekomendacijomis $(29 \%)$ ir darbuotojų paieška paskelbiant apie laisvą darbo vietą internete $(26 \%)$. 


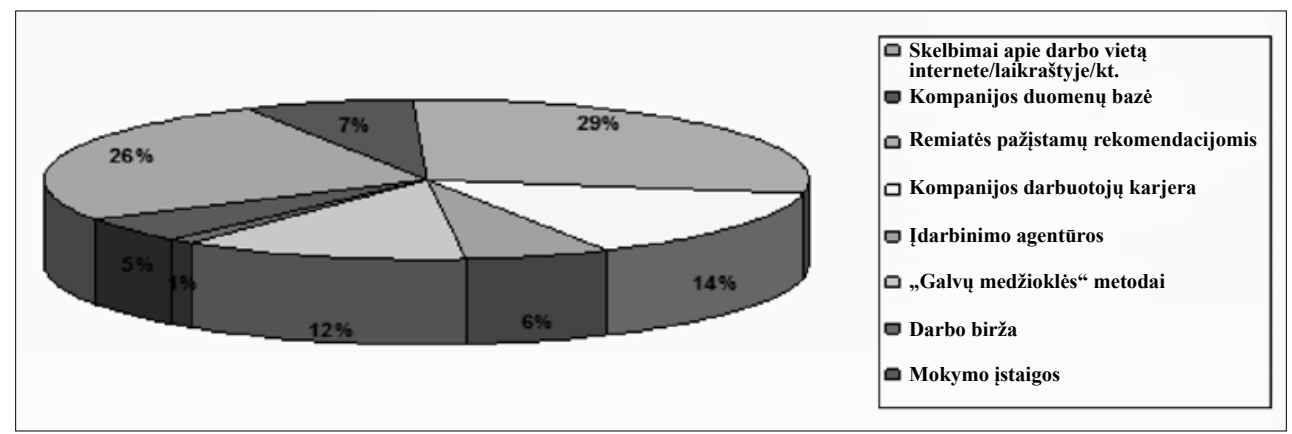

10 pav. Respondentų nuomonė apie darbuotojų paieškai naudojamus verbavimo šaltinius farmacijos organizacijose, $\%$

Pagal apklausos duomenis, vertinant aukščiausio ir vidutinio lygio vadovus, sudaryta skritulinė diagrama, parodanti talentų verbavimo šaltinius (11 pav.). Vadovai talentų verbavimo procese dažniausiai remiasi pažistamų rekomendacijomis (31\%), skelbimais apie laisvą darbo vietą internete/ laikraštyje (25\%) ir vykdo karjeros programas, kurias įgyvendinantys darbuotojai kyla karjeros laiptais užimdami laisvas/naujas darbo vietas (18 \%). Kad ir kaip būtų keista, tik $11 \%$ vadovų talentus verbuoja „galvų medžioklès“ metodais ir 4 \% peržiūri organizacijos duomenų bazes, sukauptas anksčiau vykdytų personalo paieškų metu. 7 \% vadovų kreipiasi i ịdarbinimo agentūras, $4 \%$ - ị mokymo įstaigas, $0 \%$ - į darbo biržą.

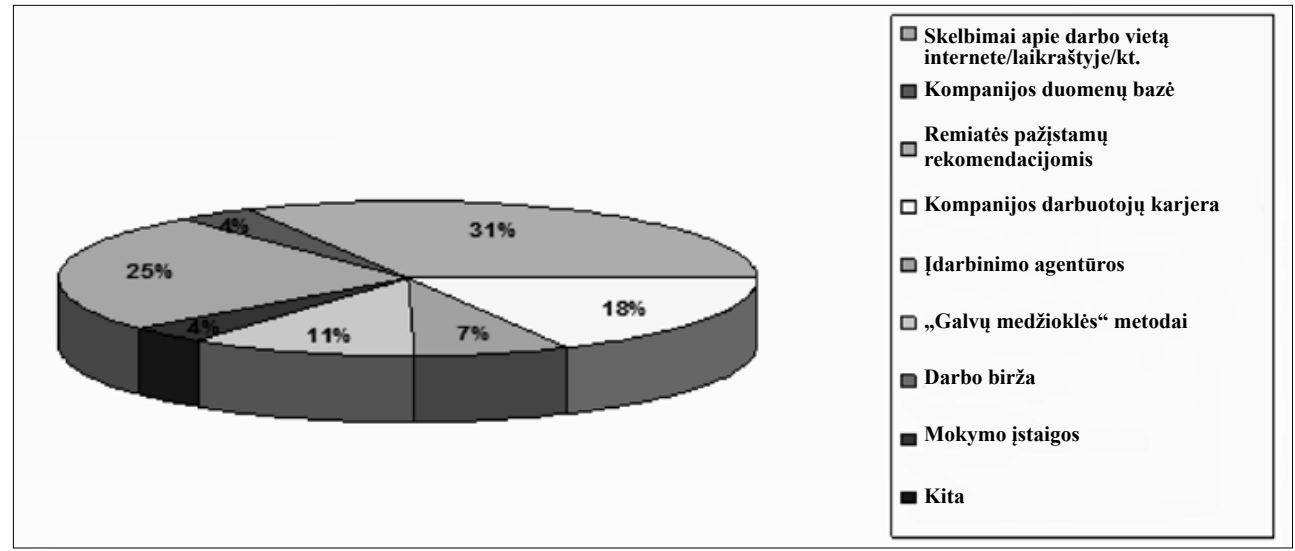

11 pav. Respondentų nuomonè apie talentų paieškai naudojamus verbavimo šaltinius farmacijos organizacijose, $\%$

Siekiant patvirtinti respondentų atsakymus dėl naudojamų personalo verbavimo šaltinių, buvo pateiktas klausimas apie jų pačių ịsidarbinimą organizacijoje. Daugelis respondentu patvirtino, kad dirbti dabartinèje organizacijoje pradejjo po pažịstamų rekomendacijos (47\%). Galima daryti išvadą, kad pažistamų rekomen- 
dacijos yra vienas svarbiausių veiksnių renkantis tiek darbovietę, tiek naują darbuotoją. $13 \%$ respondentų apie laisvą darbo vietą sužinojo internete. Darbuotojai, pasirinkę variantą „Kita“, pasiskirstè taip: $7 \%$ teigè, kad buvo pervilioti iš konkurentų „galvų medžioklès“ metodais, $3 \%$ - kad darbą rado universitete surengtą karjeros dieną (12 pav.).

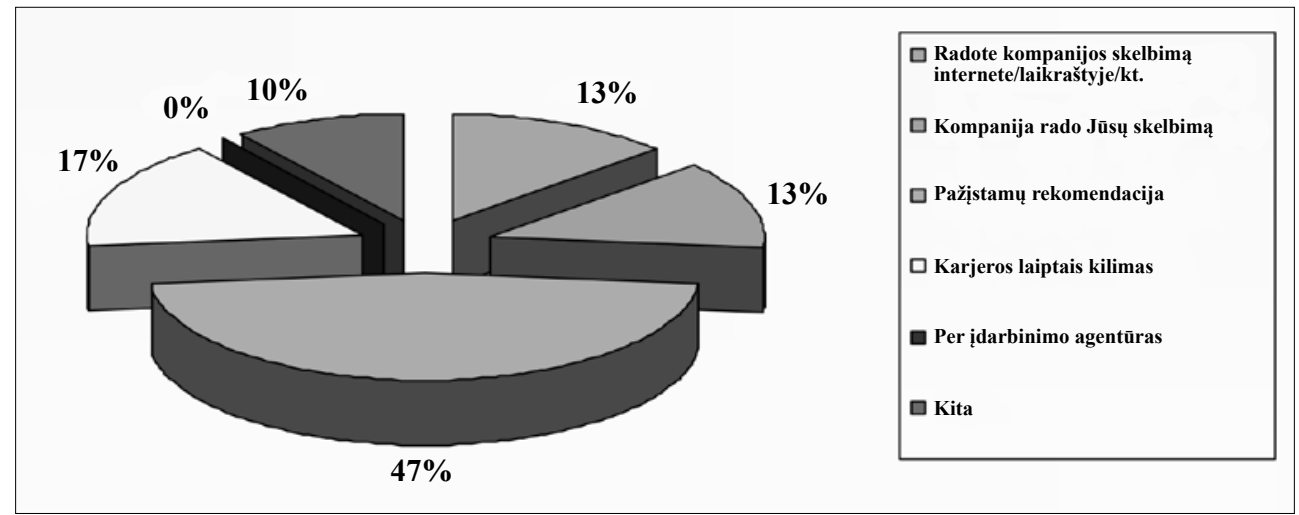

12 pav. Respondentų nuomonė apie ịsidarbinimo šaltinius, \%

Iš visų pritrauktų kandidatų organizacija turi atsirinkti geriausius. Remiantis respondentų pateiktais atsakymais buvo atlikta analizè dèl pagrindinių atrankos veiksnių svarbos. Tiek vadovų (A), tiek kitų darbuotojų nuomone (B), atrinktų kandidatų vertinimo pagrindiniai kriterijai yra labai panašūs ir pasiskirsto taip:

- Motyvacija pradèti dirbti $\sim 20 \%$.

- Kaštu ir naudos, kurią duos naujasis darbuotojas, santykis 17\%.

- Pažįstamų rekomendacijos $15 \%$.

- Darbo stažas $14 \%$.

- Kiti veiksniai sudaro likusius $34 \%$, kurie lemia apsisprendimą priimti naują darbuotoją.

Žiūreti detaliau 13 pav. (A ir B) 
A

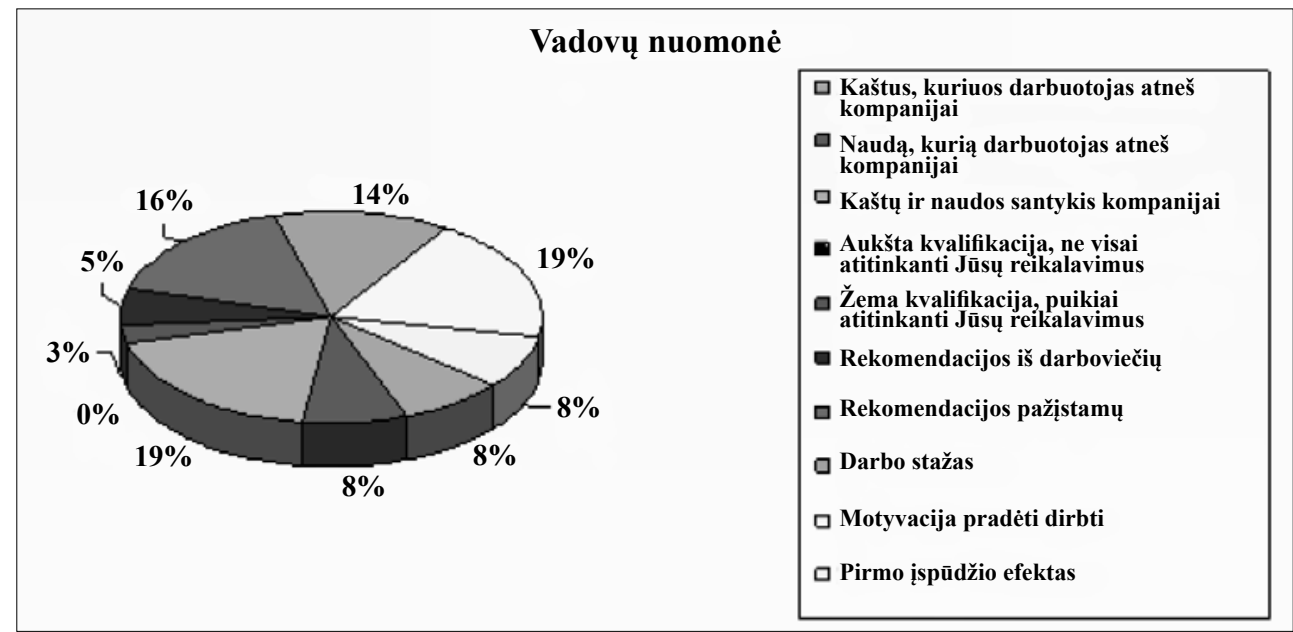

B

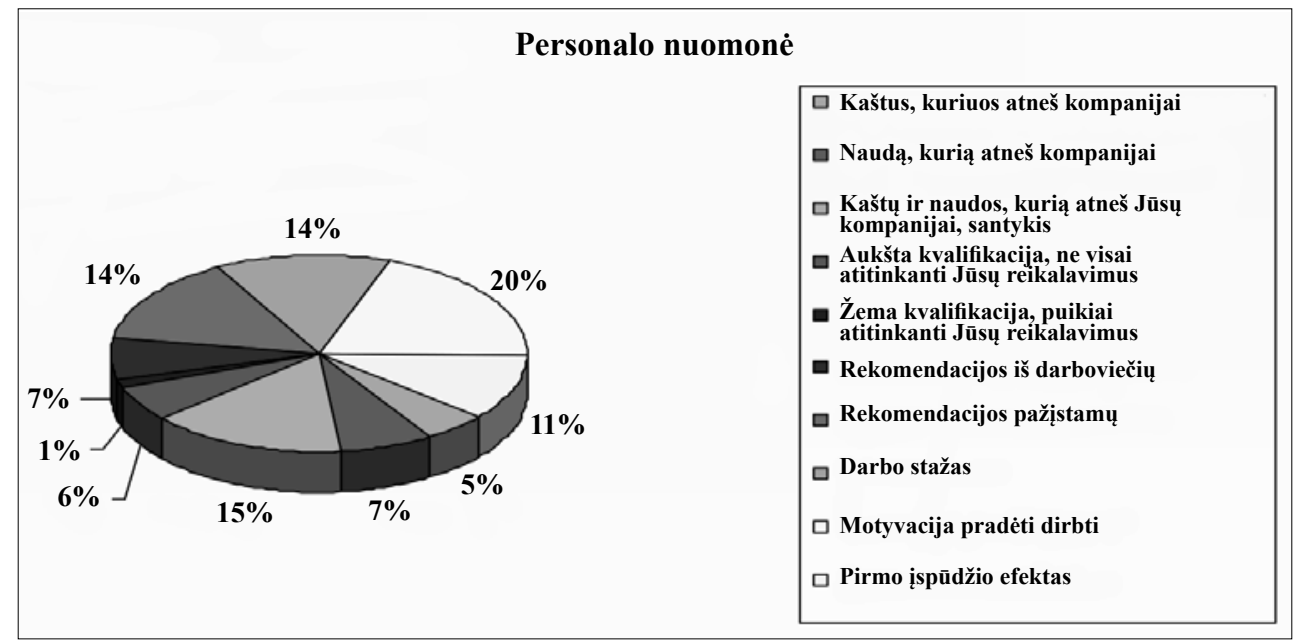

13 pav. Respondentų nuomonè apie lemiamus atrankos veiksnius, \%

Kad teigiamai ịvertintų kandidatą, vadovai labiau, nei darbuotojai, atkreipia dèmesị ị tai, kiek kainuos naujasis darbuotojas ir kokią naudą galès duoti organizacijai (+4). Vadovų nuomone, pažisstamų rekomendacijos turi didesnę įtaką teigiamam kandidato vertinimui (+2). Priešingai nei vadovų, darbuotojų nuomone, atrankos metu didesnę teigiamą reikšmę turi aukšta kvalifikacija, visiškai neatitinkanti atrankos reikalavimų (+3), ir pirmo ịspūdžio efektas $(+3)$.

Nuomonių, atsakant $\mathfrak{i}$ anketos klausimą Kokie pagrindiniai kriterijai, kuriu dèka nusprendžiate, kad naujas darbuotojas (ne)talentingas Jūsu organizacijoje?, pasiskirstymas atsispindi diagramoje „Respondentų nuomonè apie personalo talentingumo kriterijus“"(14 pav. A ir B). 


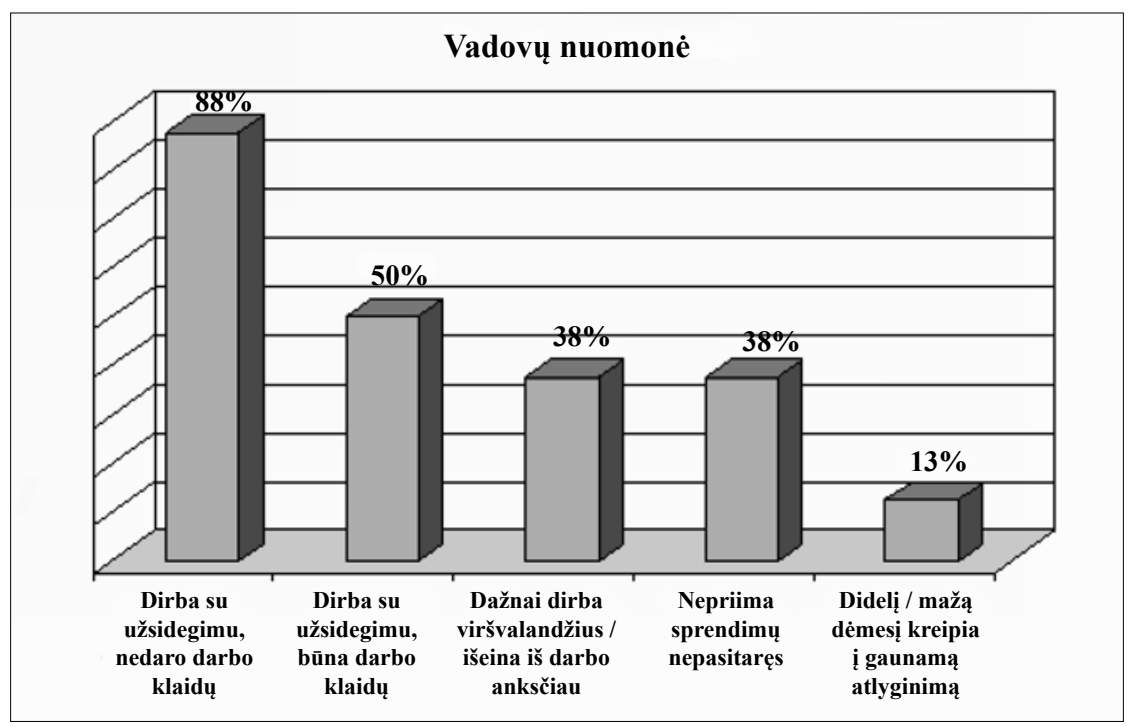

B

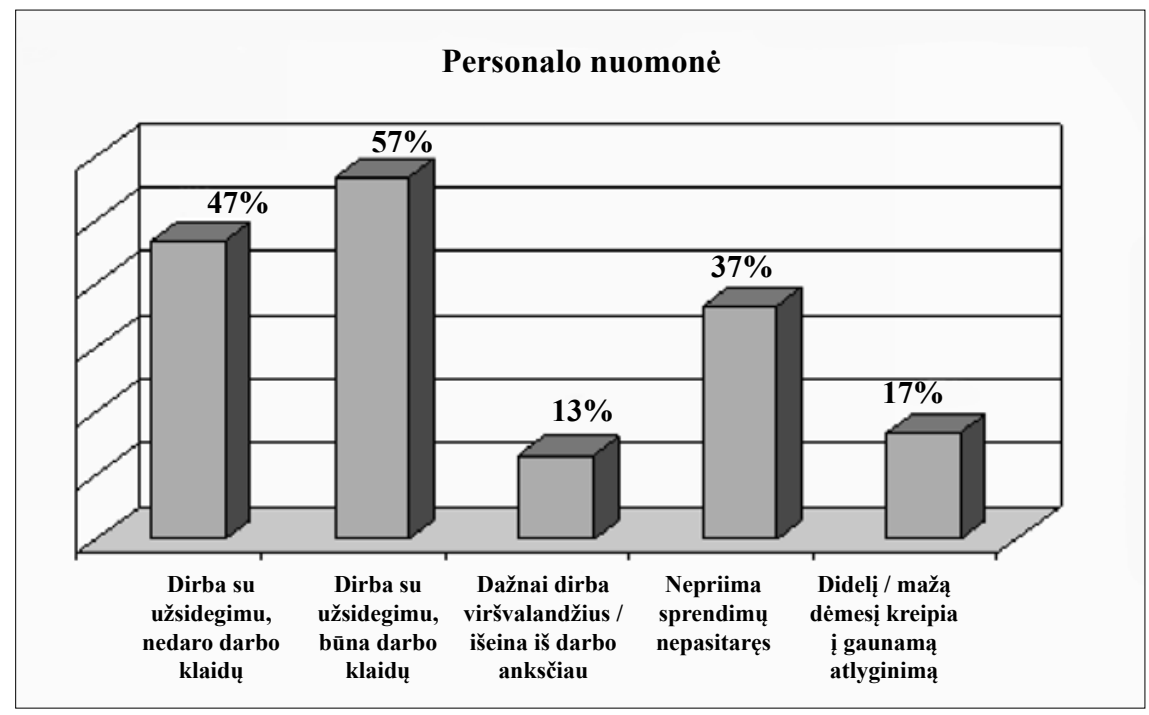

14 pav. Respondentų nuomonè apie personalo talentingumo kriterijus, \%

Remiantis 14 pav. galima teigti, kad vadovai (88 \%) (A) du kartus mažiau toleruoja darbuotojų darbo klaidas nei darbuotojai (47 \%) (B) savo kolegų. Ir vadovų, ir personalo nuomone, nauji darbuotojai turi konsultuotis su kolegomis ir nepriimti sprendimų nepasitarę ( $\sim 38 \%$ ). Vadovų nuomonę stipriau nei bendradarbių formuoja tai, kiek darbuotojas praleidžia laiko darbe. Tačiau naujo darbuotojo perspektyvumui nustatyti atlyginimas turi labai mažą įtaką (17\% darbuotojų ir $13 \%$ vadovų 
nuomone).

Vadovaudamiesi šiais verbavimo (paieškos, atrankos ir vertinimo) kriterijais $47 \%$ respondentų teigia, kad vėliausiai priimtas darbuotojas atitiko $80 \%$ visu lūkesčių. $20 \%$ respondentų teigia, kad naujai priimtas darbuotojas atitiko $100 \%$ lūkesčių. Ir tik trečdalis (27\% respondentų teigimu) atitiko $50 \%$ lūkesčių, o $7 \%$ respondentų nurodo, kad naujas darbuotojas atitiko vos $30 \%$ lūkesčių. Žiūrèti 15 pav.

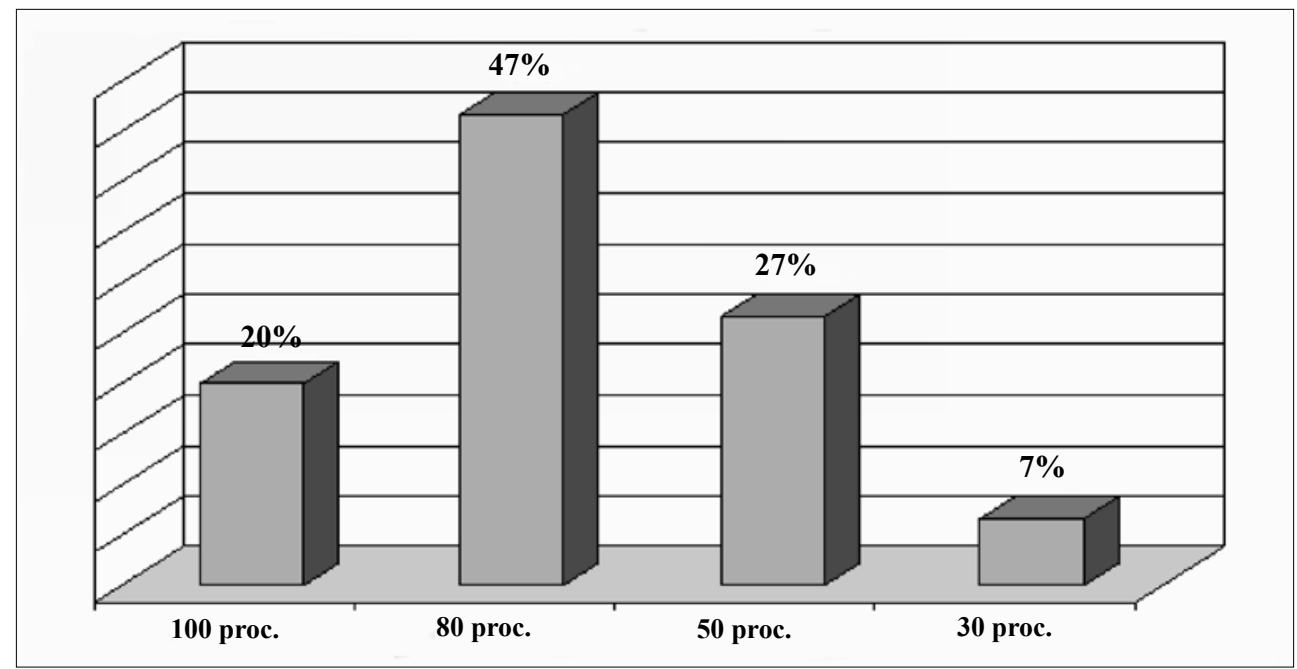

15 pav. Respondentų nuomonė apie atrankos metodų pasiteisinimą dèl lūkesčių priimtam darbuotojui, \%

Norint įsitikinti, kad atrenkami kandidatai daugeliu atvejų atitinka atrankos ir vertinimo kriterijus, pateikus anketos klausimus buvo išsiaiškinta ir darbuotoju kaitos farmacijos organizacijose tendencijos. Vertinant laiko ir darbuotojų skaičiaus santykį, šią kaitą galima laikyti labai maža. Gauti rezultatai rodo, kad per metus pasikeičia apie $10 \%$ darbuotojų, o daugeliu atvejų organizacijos didèja. Diagrama „Respondentų nuomonè apie darbuotojų judejjimą farmacijos organizacijose“ (16 pav.) rodo naujų ir palikusių organizaciją darbuotojų procentinị judèjimą. 


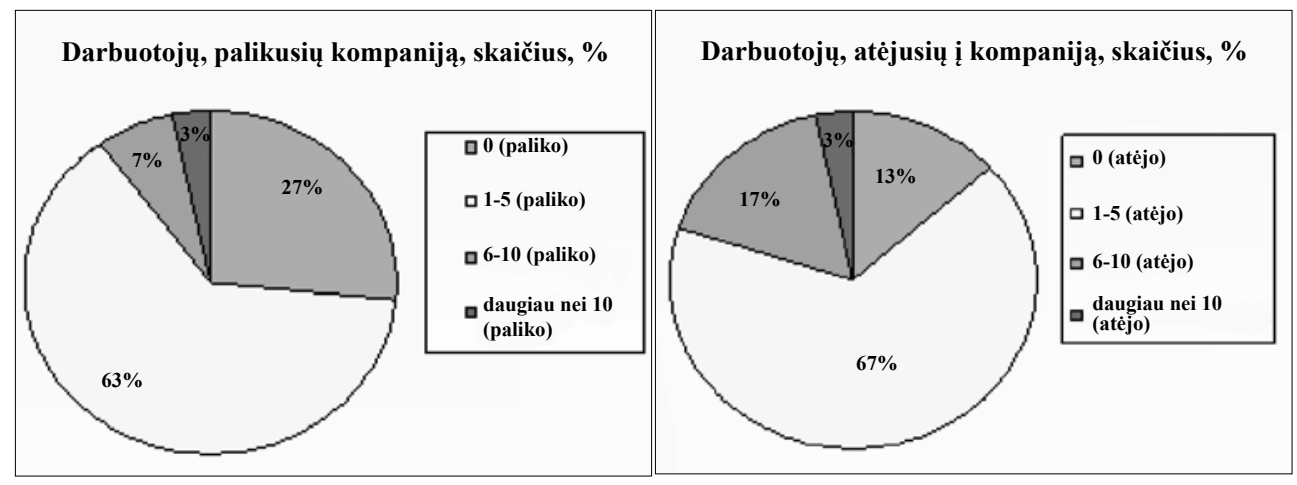

16 pav. Respondentų nuomonè apie darbuotojų judèjimą farmacijos organizacijose, $\%$

Daugelio (19) respondentų nuomone, jų organizacijoje darbuotojų kaita svyruoja - ją palieka 1-6 (63\%) ir ateina 1-6 (67 \%) darbuotojai. Keturių respondentų nuomone, organizacijos nepalieka nè vienas darbuotojas, tačiau plečiant veiklą priimama nuo 6 iki 10 naujų darbuotojų. Trys respondentai teigè, kad darbuotojų kaita buvo, tačiau bendras darbuotojų skaičius nepasikeite. Kad organizacijoje visai nebuvo darbuotojų kaitos, teigè keturi respondentai.

Siekiant išsiaiškinti darbuotojų aukšto lojalumo priežastis buvo sudaryti klausimai, padedantys nustatyti, kokie veiksniai apibūdina sèkmę darbe ir kokie motyvuoja siekti rezultatų.

Darbuotojų nuomone, sẻkmę darbe geriausiai apibūdina 3 pagrindiniai veiksniai:

- Atlyginimas ir kiti piniginiai skatinimai.

- Darbo automobilis, telefonas ir kita įranga.

- Aukštesnès pareigos.

Išsiskyrè vieno respondento atsakymas, kad asmeninè sèkmè - tai kompetencija, motyvacija ir noras tobuleti. Kiti nurodyti galimi atsakymai į 21 klausimą buvo nežymimi arba surinko mažai ir labai mažai įverčių.

Tyrimo metu buvo nustatyta, kad farmacijos kompanijose itin didelis dèmesys kreipiamas ị tai, kaip darbuotojas ịvedamas ị kolektyvą. Daugiau nei pusè (19 respondentu), t. y. $67 \%$, teigè, kad buvo ne tik supažindinti su kolektyvu, dalyvavo specialiuose mokymuose, bet ir buvo paskirtas specialistas, kuris padejo greičiau perprasti naujo darbo specifiką. Penki respondentai teigè (17\%), jog buvo asmeniškai supažindinti su kolektyvu ir jiems buvo paskirtas patarèjas, kuris padejo greičiau pradèti savarankiškai dirbti. Trijų respondentų teigimu (10\%), jie buvo supažindinti su kolektyvu, tačiau darbo specifiką perprasti reikejo patiems. Du (6\%) respondentai teigè, kad su kolektyvu susipažinti teko patiems, iš jų vienas (3\%) pripažino, jog ir naują darbą teko perprasti pačiam. 


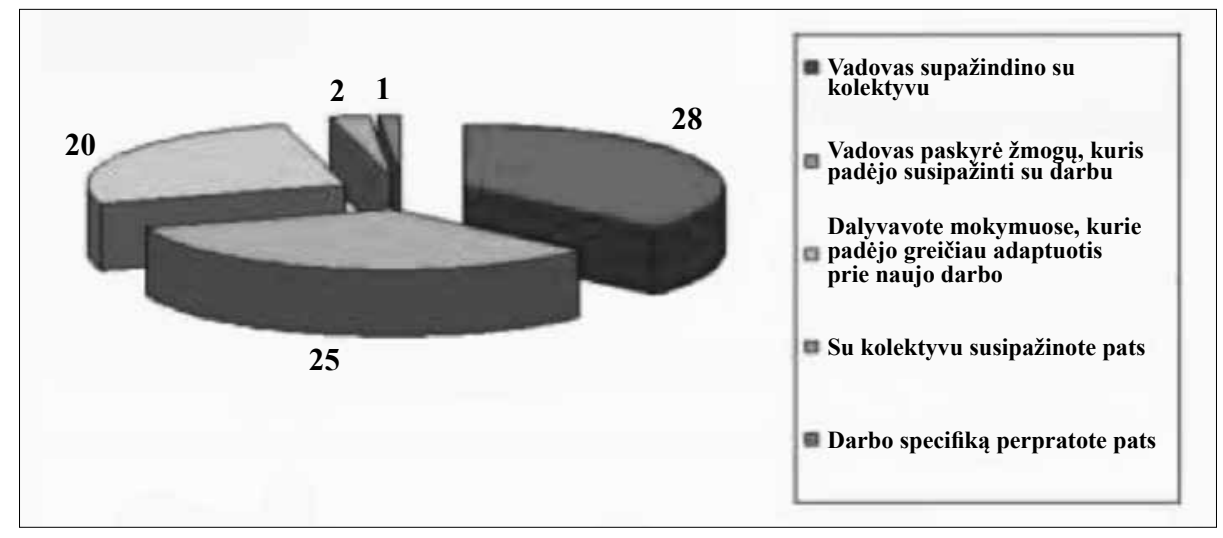

17 pav. Respondentų nuomonė apie orientavimą farmacijos kompanijose, vnt.

Pastebèta, kad farmacijos organizacijose darbuotojų kaita yra labai maža, o socializacija vykdoma atsakingai, daug dèmesio skiriama tolesniam motyvavimui. Paprastai nauji darbuotojai turi realybès neatitinkančių lūkesčių. Tie lūkesčiai gerokai pranoksta tuos, kuriuos organizacija gali patenkinti. Tai savo ruožtu lemia mažesnị pasitenkinimą darbu ir lojalumą organizacijai bei didesnę darbo migraciją (Locker, 1995).

Darbuotojo įdètos pastangos, darbo kokybė ir rezultatai priklauso nuo lūkesčių ir veiksnių, turinčiu ịtakos motyvacijos formavimuisi. Darbuotojo motyvacija labai priklauso nuo kiekvieno asmeninių savybių, gabumų ir galimybių, organizacijos vadovo valdymo stiliaus, organizacijos kultūros, vidaus ir išorinès aplinkos bei kitų veiksnių.

Organizacijos pajègumą pritraukti ir išlaikyti naujus darbuotojus lemia jos motyvavimo ir skatinimo sistema. Siekiant išsiaiškinti, kas labiausiai motyvuoja farmacijos kompanijų darbuotojus ir skatina jų lojalumą, buvo paprašyta tai ịvertinti dešimtbalèje sistemoje (10 - labiausiai motyvuoja, 1 - visiškai nemotyvuoja). Vieną įvertinimą buvo prašoma rašyti tik vieną kartą, kad respondentai gerai apsvarstytu, kurie veiksniai motyvuoja labiausiai, o kurie nemotyvuoja visai.

Apibendrinant tyrimo rezultatus galima teigti, kad apsirūpinimas talentingu personalu - vienas svarbiausių organizacijos, kuri siekia būti lyderé, uždavinių. Tyrimas parodè, kad svarbiausi veiksniai yra šie:

- Atlyginimas ir kiti piniginiai skatinimai. Ši veiksnį kaip labiausiai motyvuojantị pasirinko $37 \%$ respondentų.

- Galimybė nuolat siekti karjeros, kilti kompanijoje karjeros laiptais, išliekant lojaliems tai pačiai organizacijai. Ši veiksnị kaip labai motyvuojantị pasirinko $33 \%$ respondentų.

- Svarbios yra aukštesnès pareigos, kurias gali siūlyti konkurentai. Tai itin reikšmingas veiksnys, siekiant perverbuoti darbuotoją ,galvų medžioklès“ metodais. Ši veiksnį kaip motyvuojantị pasirinko $22 \%$ respondentų. 
Pagal apibendrintus rezultatus, darbuotojams visiškai nesvarbi demografinè organizacijos padètis, darbo inventoriaus, mokymų ir seminaru gausa.

\section{Išvados}

Apsirūpinimas talentingu personalu - vienas svarbiausių organizacijos uždavinių, kuris pasireiškia šiais pagrindiniais veiksniais:

- Siekiant plètoti kompetencija (talentais) paremtą apsirūpinimą personalu, būtų tikslinga taikyti kompetencijos (apsirūpinimo talentais) modelius - pritaikyti esamus arba plètoti naujus, siejant su esama organizacijos situacija.

- Kad apsirūpinimas talentais būtų ilgalaikis, reikia tinkamai atlikti talentų supažindinimą su darbo specifika, organizacijos kultūra, kolektyvu ir kt. Skiriami du supažindinimo etapai: technine pažintis ir socializacija.

- Lietuvos farmacijos organizacijų personalo tyrimo analizé parodè, kad apsirūpinimo talentais veiklas atlieka vadovai, neturintys specialių igūdžių ir kvalifikacijos šioms veikloms atlikti; apsirūpinimas talentais vykdomas tokiais pat metodais kaip ir kitu personalu; nustatomas neteisingas apsirūpinimo veiklų eiliškumas; didelis dėmesys skiriamas kainai; prastai išvystyta motyvuojančių veiksnių sistema.

- Farmacijos organizacijų apsirūpinimui talentingu personalu didžiausią neigiamą ịtaką daro:

- Apsirūpinimo veiklu nenaudojimas ar aplaidus požiūris ị kai kuriuos apsirūpinimo talentingu personalu etapus.

- Pažistamu rekomendacijos renkantis darbuotoją turi didelę ịtaką apsisprendimui dell kandidato kompetencijos.

- Kaštu dydis - kiek kainuos talentingas darbuotojas. Neturint metodų, kurie užtikrintų, kad talentingas darbuotojas ateis dirbti ị organizaciją, nerizikuojama investuoti ị naują darbuotoją, kurio kvalifikacija patikrinta greičiausiu būdu.

- Remiantis respondentų nuomone, orientavimas farmacijos organizacijose atliekamas sèkmingai, tačiau motyvavimo sistema nẻra gerai išplètota: plačiai naudojami remiamieji veiksniai, per mažai - motyvuojantys.

\section{Literatūra}

Amstrong, M., Baron (2002) Strategic HRM: The Key to Improved Business Performance. London CIPD.

Bakanauskienè, I. (2002) Personalo valdymas. Kaunas: VDU.

Bitinas, B. (2000) Ugdymo filosofija. Vilnius: Enciklopedija.

Brandišauskienė, A. (2007) „Gabių mokinių indentifikavimo problemos“. ActaPedagogicaVilnensia (ActaPedagogicaVilnensia), issue: 19 / 2007, pages: 42-50. Prieiga per internetą: www.smm.lt/svietimo_bukle/docs/Idalis_gabiu.doc (žr. 2014-11-15)

Cappelli, P. (2008) Talent Management for the Twenty-First Century // 
Harvard Business Review March, 2008.

Delfi naujienų portalas „Skundžiamasi talentingų vadovų trūkumu“. Prieiga per internetą: $<$ http://www.naujasdarbas.lt/index.php?info $=3 \& \mathrm{t}=$ news $\& \mathrm{~g}=445843$ E2-E3ED-41A7-829C-B942D680303A> (prisijungta $2008 \mathrm{~m}$. kovo $22 \mathrm{~d}$.)

Dessler, G. (2001) Personalo valdymo pagrindai. Kaunas: Poligrafija ir informatika.

Dubois, D. D., Rothwell, W. J., et al. (2004) Competency - Based Humans Resource Management, Davies - Black Publishing.

Ekonomikos transformavimasis: vadybos paradigma (2000). Kolektyvinè monografija. Antanavičius K., Bakanauskienė I., Kvedaravičius J. ir kt. Kaunas: VDU leidykla.

Gagné, F. (2018). Academic talent development: Theory and best practices. In S. I. Pfeiffer, E. Shaunessy-Dedrick, \& M. Foley-Nicpon (Eds.), APA handbook of giftedness and talent (pp. 163-183). American Psychological Association, https:// doi.org/10.1037/0000038-011

Gilpin, S. „YSC Consultancy Company“ konsultantas. Prieiga per internetą: $<$ http://fastleader3.cma.ee/index.php?lang=lit\&main_id=767> (prisijungta $2008 \mathrm{~m}$. balandžio 14 d.)

Grenčíková, A., Guščinskienė J., Španková, J. (2017) The role of leadership in motivating employees in a trading company // Journal of security and sustainability issues. Vilnius: Generolo Jono Žemaičio Lietuvos karo akademija. ISSN 20297017. eISSN 2029-7025. 2017, 7, 2, p. 247-257. DOI: 10.9770/jssi.2017.7.2(6). [Scopus; Lituanistika; Academic Search Research and Developement (EBSCO)] [CiteScore: 2,08; SNIP: 1,090; SJR: 0,473; Q1 (Scopus Sources)].

Grakauskaitė-Karkockienè, D. (2003) Kūrybos psichologija. Vilnius: Logotipas.

Grakauskaitė-Karkockienė, D. (2006) Kur dingsta Kodėlčiukai? Vilnius: Logotipas.

Gross, M. U. M. Issuesinthecognitivedevelopmentofexceptionall-yandprofo undlygiftedindividuals// Heller, K. A., Mönks, F. J., Sternberg, R. J., Subotnik, R. F. (Eds) (2000) International handbookofgiftednessandtalent (2nd edition). Oxford: ElsevierScience Ltd., p. 179-192.

Goldstein, L. D. Davison, A. D. (1998) Hiring the Right Stuff: Using Competency Based Selection // Compensation and Benefits Management No 3.

Good, C. V. (1959) Dictionary of education N.Y. Toronto, London: McdrawHillbook Company.

Greenberg, J. and Baron, R. A. (2007) Behavior in Organizations (9th edition), New Jersey: Prentice Hall.

Grzeda, M. M. (2001) Managerial Competence: Considerations for Resolving Conceptual Ambiguity. Academy of Management, Annual Meeting, 2001.

HRfocus (2008) Talent Management Tips From Tree Successful Companies 2008, HRfocus New Briefs, March. 
Išplèstinis farmacinių kompanijų sąrašas. Prieiga per internetą: $<$ http://www. search.lt/browse.asp? $\mathrm{id}=185$ \&lang $=\mathrm{L}>$ (prisijungta $2008 \mathrm{~m}$. kovo $7 \mathrm{~d}$.)

Ivanovic, A., Collin, P. (1997) Dictionary of Humans resources and Personnel Management Peter Collin Publishing Ltd.

Jatautaite, D., Kazimianec, J. (2018). The importance of sustaining secure ambience for cadets of the Military academy of Lithuania via balancing emotions and perception in attaining accelerated second language learning and acquisition // Journal of security and sustainability issues. Vilnius: Generolo Jono Žemaičio Lietuvos karo akademija.

Jucevičienè, P. (1996) Organizacijos elgsena. Kaunas: Technologija.

Katkevičius, A. (2007) „Rezultatas turi būti pats žmogus“// Verslo žinių priedas „Verslo klasë“, 2007 spalis.

Kauno technologijos universitetas, Socialinių mokslų fakultetas (2006). Žmogiškieji santykiai. Kaunas: Technologija.

Klebanskaja, N. (2006) // Paskaitų konspektas.

Kolbe, K. (2002) Powered by Instinct: 5 Rules for Trusting Your Guts. Monumentus Press.

Lepaitè, D. (2003) Kompetenciją plètojančių studijų programų lygio nustatymo metodologija. Kaunas: Technologija.

Lindsay, P., Stuart, R. (1997) Reconstructing competence // Journal of European Industrial Training, No 8-9.

Liutkevičienè, I. (2006) „Psichologinis ginklas“ // Verslo žinių priedas „Verslo klasè“, 2006 rugpjūtis.

Locker, D. J. (1995) Business and Administrative communication, Chicago: Foreman and company.

Mileška, A. „Darbdavio įvaizdis: investicijos talentams pritraukti ir išlaikyti“. Prieiga per internetą: $<\mathrm{http}: / / w w w . m a n a g e r . l t / k a r j e r a / i n d e x . p h p ? \mathrm{st}=12>$ (prisijungta $2008 \mathrm{~m}$. kovo 8 d.)

Misevičius, V. „Personalo atrankos būdai“. Prieiga per internetą: <http:// verslas.banga.lt/lt/patark.full/3c5454b67ec4d $>$ (prisijungta $2008 \mathrm{~m}$. kovo $10 \mathrm{~d}$.)

Mönks, F. J. , Ypenburg, I. H. (2003) Mūsų vaikas nepaprastai gabus. Kaunas: Šviesa.

Nohria, N. Joyce, W. and Roberson, B. (2003) What Really Works? // Harvard Business Review.

Petkevičiūtè, N., Kaminskyte, E. (2003) „Vadybinė kompetencija: teorija ir praktika“// Pinigų studijos 2003.

Powell, R. R. and Connaway, L. S. (2004) Basic Research methods for librarians. Westport CT.: Libraries unlimited.

Robert, W. White (1959) Motivation reconsidered: The concept of competence // Psychological Review.

Robert, W. White (1959) Study of Lives: Essays on Personality in Honor of Henry A. Murray. 
Sakalas, A. (1998) Personalo vadyba. Vilnius: Margi raštai.

Savickienè, I. „Profesionalios darbuotojų atrankos užkaboriai“. Prieiga per internetą: $<$ http://pbcentras.w3.lt/cenxem_dartuz.php $>$ (prisijungta 2008 m. balandžio 8 d.)

Sokol, J. (2001) „Idealaus vadybininko portretas“// Vadovo pasaulis, Nr. 9.

Stoner, J. A. F., Freeman, R. E., Gilbert, D. G. (1999) Vadyba. Kaunas: Poligrafija ir informatika.

Švėgždaitė, D., gyd., Vilniaus visuomenès sveikatos centras, „Itampa darbe“. Prieiga per internetą: <http://www.vilniausvsc.lt/gyvenimo_budas/mobingas.htm> (prisijungta $2008 \mathrm{~m}$. gegužès 19 d.)

Torrington, D., Hall, L. (1998) Human Resource Management. New York: Prentice Hall Int.

$\mathrm{UAB}$ „AD Gloriam karjeros centras“, „Individualus požiūris į darbuotojų motyvaciją“. Prieiga per internetą: $<$ http://www.karjeroscentras.lt/lt.php/patarimai/ darbuotoju_motyvacija/27746> (prisijungta $2008 \mathrm{~m}$. kovo $7 \mathrm{~d}$.)

Ulrich, D., Brockbank, W. (2007) Personalo vadyba: vertès pasiūlymas. UAB „Verslo žinios“: UAB „Logotipas“.

Vaitkevičiūtè, V. (2001) Tarptautinių žodžių žodynas. Vilnius: Žodynas.

Vasiliauskas, A. (2002) Strateginis valdymas. Vilnius: Enciklopedija.

Žaptorius, J. (2007) „Darbuotojų motyvavimo sistemos kūrimas ir jos teorinè analizé“// Filosofija, Sociologija, 2007, t. 18, Nr. 4. Lietuvos mokslų akademijos leidykla. 


\title{
TALENTED PERSONNEL RECRUITMENT FACTORS: THE CASE OF PHARMACEUTICAL ORGANIZATIONS
}

\author{
Assoc. prof. Dr. Dileta Jatautaitė \\ The General Jonas Žemaitis Military Academy of Lithuania
}

Indrẻ Janušauskienė

\section{Summary}

One of the most important organizational capitals discovered in the twenty first century which assures successful organizational activities is the talented personnel. Therefore, the aim of the article is to figure out: what the talent personnel is and how to keep it in the organization so that it would stay and work in the same place. Moreover, it is also significant to attract and to try to maintain talented personnel with incentives and other motivational assets in the case of pharmaceutical organizations. To achieve the aim of the paper and to realize the objectives, an electronic questionnaire was created and submitted to the administrative staff (managers and specialists) of pharmaceutical organizations to answer it. Owing to the collected data, the importance of talents in organization was determined, and the motivational factors of talented employees were analyzed, which are important for the retention of the staff and their efficiency in their work. The analysis of the data has been used and applied to the formulation of proposals.

The results of the study have helped to identify and analyze the problem areas faced by pharmaceutical organizations in terms of talent acquisition and motivation for effective and efficient performance in the organization. Therefore, the paper analyses the results of the study, which will help to discover the most effective motivational methods necessary for retaining talent and improving the situation in the organization in terms of talent acquisition, including more activities or improving the implementation of existing activities. Talent management is one of the most important tasks for an organization, and it involves familiarization with the specifics of the job, the culture of the organization, the team, etc. The analysis of the Lithuanian pharmaceutical organizations' personnel survey has shown that talent acquisition activities are carried out by managers who do not have special skills and qualifications to carry out these activities; talent acquisition is carried out by the same methods as for other personnel; the wrong sequence of acquisition activities is applied; the research is also focused on labor cost and reward system, which results in a poorly developed system of talent motivating factors, which is very central for the promotion of quality and efficiency of the organization.

Keywords: talent, aptitude, motivation, pharmaceuticals, organization, personnel, recruitment 


\section{AUTORIŲ LYDRAŠTIS}

Autoriaus vardas, pavardè: Dileta Jatautaitè

Mokslo laipsnis ir vardas: socialinių mokslų daktarè, docentė

Darbo vieta ir pareigos: Generolo Jono Žemaičio Lietuvos karo akademijos docentè

Autoriaus mokslinių interesų sritys: psicholingvistika, glotoedukologija, edukologija, tradiciniai ir netradiciniai kalbų mokymo metodai, psichoedukologiniai kalbų mokymo ir išmokimo pagrindai, glotoedukologija

Telefonas ir el. pašto adresas: (8 5) 210 3560;

dileta.jatautaite@mil.1t,dileta.jatautaite@1ka.1t

Autoriaus vardas, pavardė: Indrẻ Janušauskienė

Mokslo laipsnis ir vardas:

Darbo vieta ir pareigos:

Autoriaus mokslinių interesų sritys: projektų vadyba, administravimas, personalo valdymas

Telefonas ir el. pašto adresas: janusauskiene.indre@gmail.com

\section{AUTHORS' COVER LETTER}

Author's name and surname: Dileta Jatautaitè

Academic degree and name: Associate Professor, Doctor

Workplace and position: General Jonas Žemaitis Military Academy of Lithuania

Author's research interests: psycholinguistics, glotoeducology, neurolinguistics, traditional and non-traditional language teaching methods and methodology, psycho-educational basis in language learning and acquisition.

Telephone and e-mail address: +370 5210 3560; dileta.jatautaite@mil.lt; dileta.jatautaite@1ka.1t

Author's name and surname: Indrè Janušauskienè

Academic degree and name:

Workplace and position:

Author's research interests: project management, administration, personnel management

Telephone and e-mail address: janusauskiene.indre@gmail.com 